\title{
Using Endemic Rubiaceae of the Lower Guinea Domain to Locate the Priority Sites for Conservation in Cameroon
}

\author{
Hermann Taedoumg ${ }^{1 *}$, Louis-Paul Roger Kabelong Banoho ${ }^{1}$, Nicole Liliane Maffo Maffo ${ }^{1}$
}

${ }^{1}$ Department of Plant Biology, Faculty of Science, University of Yaoundé 1, P.O. Box 812, Yaounde, Cameroon

DOI: $10.36347 /$ sajb.2021.v09i03.003

| Received: 07.02.2021 | Accepted: 15.03.2021 | Published: 20.03.2021

*Corresponding author: Hermann Taedoumg

Abstract

Original Research Article

From herbarium specimens and literature review of Rubiaceae, we established a list of 387 endemic taxa (species, subspecies and varieties) from Lower Guinea Domain, with 288 present in Cameroon. Two hundred and three taxa having specimens from BM, BR, BRLU, P, K, MO, SCA, WAG, and YA were taken into account in our analyses. The specific diversity was determined by counting the number of species per grid square with Arc view 3.3. The distribution maps are obtained by projecting the coordinates of collecting sites on map of Cameroon. It appears that there are several hotspots of Rubiaceae in Cameroun. Four principal zones are distinguished: Mount Cameroon area (86 taxa), Kupe and Bakossi area (66 taxa), Bipindi-Akom II area (68 taxa), and Yaounde and its surroundings (28 taxa). The most significant factor to explain the endemism and the specific richness of Rubiaceae in Cameroun is altitude. The high precipitation and the continental gradient also play an important role in explaining this richness. The confinement of endemic Rubiaceae in Atlantic forests seems to be an argument in favor of this hypothesis. The area around Yaoundé and the massifs around Bipindi have no conservation status. Both areas are under permanent threat from logging and slash-and-burn agriculture and from ever-increasing population pressures. There is an urgent need for conservation measures to be taken to protect these forests, the importance of which is highlighted in this study. Yaounde is a large urban agglomeration and the easily accessible hills could be, in the medium term, financially viable through ecotourism.

Keywords: Rubiaceae, Distribution, Specific richness, Endemism, Lower Guinea Domain, Cameroon.

Copyright (C) 2021 The Author(s): This is an open-access article distributed under the terms of the Creative Commons Attribution 4.0 International License (CC BY-NC 4.0) which permits unrestricted use, distribution, and reproduction in any medium for non-commercial use provided the original author and source are credited.

\section{INTRODUCTION}

The conclusions of the 1992 United Nations Conference in Rio de Janeiro state that biodiversity refers to the variability of living organisms from all sources, including terrestrial, marine and aquatic ecosystems and the ecological complexes of which they are part. Biodiversity is therefore the basis for the proper functioning of ecosystems that provide essential goods and services for human subsistence. Natural resources have always been used to meet the primary needs of communities, not only to provide food, fuelwood, and building materials, but also to enable the economic (small- and large-scale), social, and cultural development of peoples [1]. Areas teeming with rich biodiversity generally tend to blend in with those with some of the world's poorest populations [2]. With an area of over 2,000,000 km2, the forests of Central Africa is, after the Amazon, the second largest forest on our planet [3]. The forests present in Cameroon, Equatorial Guinea and Gabon constitute about $20 \%$ of this large forest complex. Although it represents large areas, this forest resource is now more threatened than ever by human activities (industrial plantations, industrial logging) and galloping demography.

Tropical forest conservation is currently a major issue; any research to protect significant areas from deforestation is justified. Conservation requires an understanding of the historical processes of vegetation establishment and evolution, as the maintenance of specific and genetic diversity certainly depends on the latter factors. The location of forest refuges is an important tool in this regard. The location of forest refuges is an important tool in this regard. Indeed, these refuges constitute areas where lowland and mountain forests have been maintained during past climatic changes, in particular, the last ice ages $(18,000$ years ago); this has favored the development of a certain endemism [4]. Studies conducted in Africa on Begonia [5-7] have shown that these refuges constitute sites with a very high specific richness and endemism rate. The development of a method based on the study of indicator species allowing the location of sites with high biodiversity without carrying out exhaustive inventories would be welcome. 
Rubiaceae family includes about 650 genera and nearly 13,100 species [8], placing it, after the Asteraceae, Orchidaceae, and Fabaceae, among the largest families of Angiosperms. The most famous and economically valuable genus of the family is Coffea $\mathrm{L}$. Coffee is the most traded product in the world after oil [8]. Other economically important Rubiaceae include Cinchona officinalis L. (quinine), Pausinystalia johimbe (K. Schum.) Pierre (yohimbine, aphrodisiac), Nauclea diderrichii (De Wild. \& T. Durand) Merr. (Bilinga, timber), species of Genipa L. (genipapo, beverage), Calycophyllum DC. (lumber) and Gardenia J. Ellis (perfume). The family also contains some of the most beautiful tropical ornamental plants (Ixora L., Gardenia L., Mussaenda L.). Rubiaceae is a cosmopolitan family; it is a tree, shrub, vine or herbaceous plant widely distributed in tropical, subtropical and temperate regions. Most representatives of the family are located in tropical and subtropical regions. Rubiaceae are present in all vegetation strata and can sometimes represent up to $50 \%$ of the total understory biomass, thus playing an important ecological role at all levels [9]. The Rubiaceae of temperate regions are exclusively herbaceous and the number of species in the family is limited. This vast and taxonomically complex family has aroused a growing interest in the last few decades, initiated by the publication of "Tropical Woody Rubiaceae" [10]. This pioneering text gives an overview of the characters (mainly morphological and anatomical, but also biological and chorological) of the tropical woody Rubiaceae, proposes a classification of the group, draws up an inventory of the gaps in knowledge of the family at the time and suggests avenues for future taxonomic research.

The present contribution is part of the research on Rubiaceae and Orchidaceae undertaken to study the diversity and distribution of Rubiaceae endemic to the Guinean-Congolian region in Cameroon [11]. The objective is to locate sites with high diversity and endemism rates for Rubiaceae. These sites can therefore be prioritized for protection in order to conserve biodiversity as effectively as possible. This localization is, in our opinion, the first step in the conservation effort.

More specifically, the objectives of this paper are (i) to constitute a database of the Rubiaceae of the LGD including all the taxa of this zone, using the available herbarium specimens, the geographical distribution, the ecological data (altitude, habitat), (ii) to establish a general distribution map of the species present in Cameroon and finally (iii) to recommend sites that can be prioritized in conservation actions in Cameroon.

The Guinean-Congolian region is subdivided into 3 domains. The Upper Guinean Domain, the Lower Guinean Domain (LGD) and the Congolese Domain.
The LGD is the region that encompasses southeastern Nigeria, Equatorial Guinea, Gabon, Congo, the enclave of Cabinda, the islands of the Gulf of Guinea (Bioko, Annobon, Sao Tome and Principe), and the southern part of Cameroon [12].

\section{MATERIAL ET METHODS}

This study is based on the examination of herbarium specimens available at the Yaoundé National Herbarium (YA), the Limbe Botanical Garden (SCA) herbarium as well as those collected during our field trips. In addition, samples from BM, BR, BRLU, K, P, and WAG were also included, abbreviations follow Holmgren et al., [13]. In total 2364 herbaria specimens were considered in this work.

Data used to set the list of endemic Rubiaceae of the LGD were obtained from several sources: (i) the "World Checklist" of Rubiaceae available on the Kew Botanical Garden Herbarium website; (ii) examination of herbarium samples collected in Cameroon and available at BM, BR, BRLU, K, MO, P, SCA, WAG, and YA; (iii) the bibliography on the Rubiaceae family in Africa and Cameroon; (iv) the Rubiaceae section of the Mount Cameroon Plant Checklists [14], Mount Oku [15], Mount Kupe [16] and Bali Nguemba [17].

Two hundred and three taxa are included in the analyses for Cameroon, as they have samples present in the herbaria mentioned above. It should be noted however, that only samples from YA and SCA were examined and databased, i.e. 1051 specimens. The habitats of each species where were collected. A species reported several times and exclusively in the same environment is said to be exclusive of this habitat. The information comes from the herbarium sheets and from our field observations. The distribution maps were obtained by georeferencing the collection sites and exporting them to Arc View 3.3. Specimens with lacking geographic coordinates (on the herbarium sheets), are georeferenced from gazetter 60 [18]. Species richness reflects the number of taxa present in a given grid cell. Cameroon was divided into grids of different sizes $(0.5$ degree and 1 degree square). These grids are established with "Mila Utilities 3.2" and "Geoprocessing" extensions of Arc View 3.3. Calculation of the number of species and genera present in each grid was done with the extension "Counts Points in Polygon".

\section{RESULTS \\ ENDEMISM AND SPECIFIC RICHNESS OF THE LOWER GUINEA DOMAIN}

Three hundred and eighty-two taxa (species, subspecies, variety) from 63 genera are endemic to the LGD. With 288 taxa from 46 genera, Cameroon is the center of diversity of Rubiaceae endemic to the LGD (Table-1). 
Hermann Taedoumg et al., Sch Acad J Biosci, Mar, 2021; 9(3): 68-83

Table-1 Number of taxa endemic or present in each LGD country

\begin{tabular}{|l|l|l|l|l|l|}
\hline \multicolumn{2}{|l|}{} & \multicolumn{2}{l|}{ Endemic species of the DBG } & \multicolumn{2}{l|}{$\begin{array}{l}\text { Species strictly endemic to the } \\
\text { country }\end{array}$} \\
\hline Country & Area $\left.\mathbf{( k m}^{2}\right)$ & $\begin{array}{l}\text { Number of } \\
\text { taxa }\end{array}$ & $\begin{array}{l}\text { Number of taxa } \\
/ 100 \mathbf{~ k m}^{2}\end{array}$ & $\begin{array}{l}\text { Number of } \\
\text { taxa }\end{array}$ & $\begin{array}{l}\text { Percentage of } \\
\text { total }(\%)\end{array}$ \\
\hline Cameroun & 475440 & 288 & 0,06 & 149 & 51,73 \\
\hline Gabon & 267670 & 158 & 0,05 & 62 & 39,24 \\
\hline Congo & 342000 & 18 & 0,005 & 3 & 16,66 \\
\hline Equatorial Guinea & 26000 & 31 & 0,11 & 3 & 9,67 \\
\hline Nigeria & 923770 & 63 & 0,006 & 1 & 0,01 \\
\hline Cabinda & 7270 & 20 & 0,27 & 5 & 25,00 \\
\hline Islands of the Gulf of Guinea & 964 & 38 & 3,94 & 10 & 26,31 \\
\hline
\end{tabular}

Rubiaceae Endemic to the LGD are reported from Gabon with 158 taxa, followed by Nigeria with 63 taxa, the Gulf of Guinea countries with 38 taxa, Equatorial Guinea with 31 taxa, the Cabinda enclave with 20 taxa and finally Congo with 18 taxa. The number of genera per country follows almost the same trend. Meaning that, the number of genera decreases from Cameroon to Congo, passing through Gabon, Nigeria, Equatorial Guinea, the Gulf of Guinea islands and Cabinda.
To better appreciate the floristic similarity between Cameroon and the other LGD countries, species were divided into four categories (Fig-1):

- 1st category: species common between Cameroon and each of the countries of the LGD considered;

- 2nd category: species absent from Cameroon and present in each of the countries considered;

- 3rd category: species present in Cameroon and absent from the LGD country considered;

- 4th category: species absent from Cameroon and from each of the countries considered.

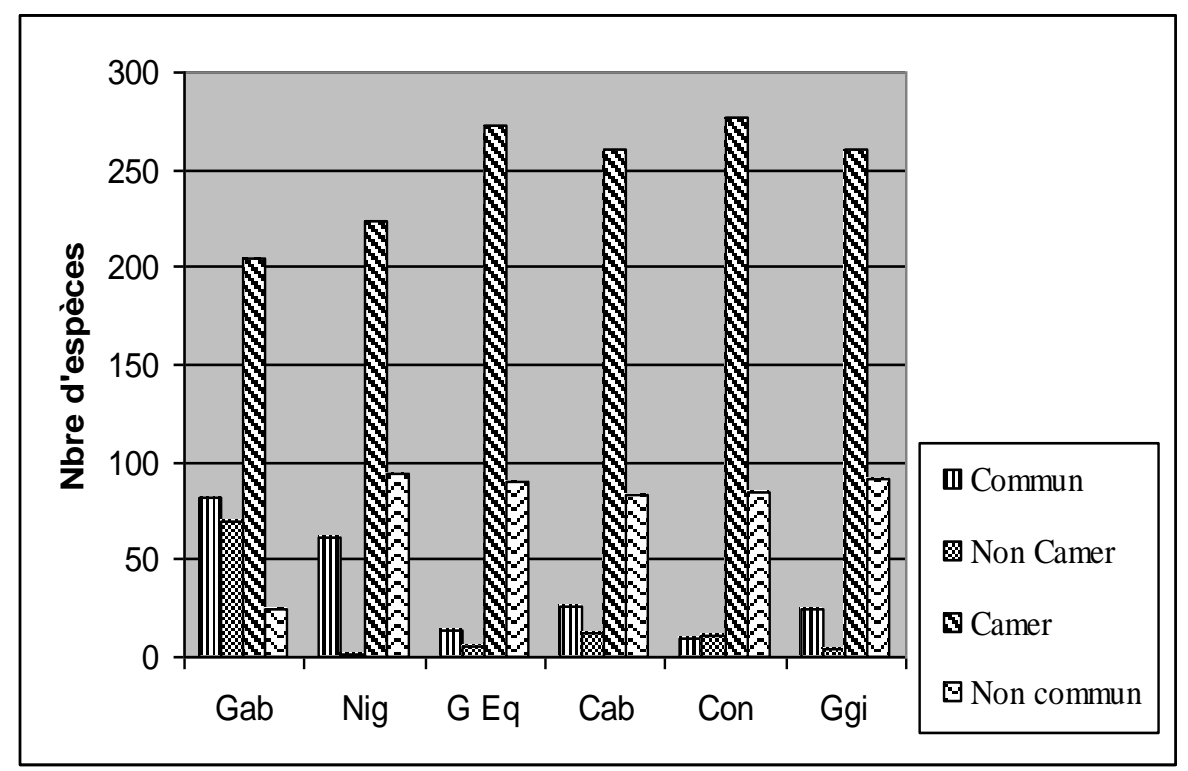

Fig-1: Specific similarities between Cameroon and each country of the Lower Guinea Domain

$(\mathrm{Gab}=$ Gabon, Con $=$ Congo, $\mathrm{GEq}=$ Equatorial Guinea, $\mathrm{Cab}=\mathrm{Cabinda}, \mathrm{Nig}=$ Nigeria, $\mathrm{Ggi}=$ the Gulf of Guinea countries, commun: species present in both countries; non camer: species absent from Cameroon, but present in the country; Camer: species present in Cameroon, but absent from the country; non commun: species absent in Cameroon and in the country)

Gabon and Nigeria share 82 and 64 species with Cameroon respectively, while the others, including Equatorial Guinea, share less than 27 species with Cameroon. Similarly, Gabon has 73 species absent from
Cameroon, while Nigeria has only one, Sabicea urceolata. Congo and Cabinda have the fewest species in common with Cameroon, 13 and 9 species respectively. Equatorial Guinea, which shares a border with Cameroon, has a low floristic similarity with this country. However, we should expect a higher similarity close to what is observed for Nigeria and Gabon.

In terms of strict endemics, Cameroon and Gabon, with 149 and 62 species respectively, have the highest number of species (Table-1). There are no LGD species strictly endemic to Nigeria. The number of 
Hermann Taedoumg et al., Sch Acad J Biosci, Mar, 2021; 9(3): 68-83

endemic LGD species present in each country is also high in Cameroon and Gabon.

With the exception of Pavetta owariensis var. glaucescens, and Sherbounia hapalophylla var. hapalophylla, no species covers the entire LGD. Aulacocalyx caudata, Mussaenda polita, Pauridiantha canthiifolia, Pausinistalya johimbe and Vangueriella chlorantha occur in Nigeria, Cameroon, Gabon and Equatorial Guinea. These four countries share the coastline that forms a continuum from Nigeria to Equatorial Guinea. Sabicea urceolata is the only LGD species strictly endemic to Nigeria.

At the generic level, Psychotria and Pavetta, with respectively 60 and 45 species, represent about $27 \%$ of the total number of endemic Rubiaceae species of the
LGD. All the species of the genus Coffea endemic to the LGD are present only in Cameroon and Gabon, the same is true for the genus Gaertnera.

\section{RUBIACEAE ENDEMIC TO THE LOWER GUINEA DOMIN PRESENT IN CAMEROON}

Ecology of species

Specimens were collected from a wide variety of habitats. However, Rubiaceae seem to prefer certain ecological environments. This is the case in particular of zones with high humidity and high altitude zones (Table-2). This observation has already been made by Nguembou [19] and Beina [20] who report the presence of most Rubiaceae, especially Hedyotideae, in humid areas. The submontane forests present the greatest number of exclusive taxa (Rothmannia ebamutensis, Coffea fotsoana, Chassalia laikomensis...).

Table-2: Habitats and exclusive species.

\begin{tabular}{|l|l|l|}
\hline Habitats & $\begin{array}{l}\text { Number of } \\
\text { species }\end{array}$ & Exclusive species \\
\hline $\begin{array}{l}\text { Secondary roadside vegetation } \\
\text { in forests }\end{array}$ & 27 & Sabicea gabonica \\
\hline $\begin{array}{l}\text { Wetlands (stream banks, } \\
\text { wetlands, forest galleries) }\end{array}$ & 91 & $\begin{array}{l}\text { Belonophora ongensis, Bertiera elabensis, Bertiera rosseeliana, Ixora } \\
\text { euosmia, Tricalysia lasiodelphys, Virectaria angustifolia, Sherbounia } \\
\text { buccularia. }\end{array}$ \\
\hline Forest edge & 7 & None \\
\hline Degraded forest undergrowth & 12 & None \\
\hline Shaded forest undergrowth & 43 & None \\
\hline Submontane and montane & 61 & $\begin{array}{l}\text { Alacocalyx camerouniana, Aulacocalyx mapiana, Chassalia } \\
\text { laikomensis, Coffea montekupensis, Ixora foliosa, Psychotria foliosa, } \\
\text { Rothmannia ebamutensis, Coffea fotsoana, Pavetta hookeriana var. } \\
\text { hookeriana, Sabicea urbania }\end{array}$ \\
\hline Ruderal areas and crops & 33 & Bertiera arctistipula \\
\hline Forest on volcanic soil & 27 & None \\
\hline Lighted forest & 17 & None \\
\hline
\end{tabular}

\section{Distribution and species richness of endemics present in Cameroon}

A total of 2364 georeferenced herbarium specimens were included in the mapping. Several maps were elaborated in this work: a topographic map of Cameroon obtained by the MTN (Digital Terrain Model) (Fig-2). This map also mentions the main peaks of Cameroon and some of the most reported localities in the herbarium sheets; a general distribution map of Rubiaceae endemic to the LGD in Cameroon (Fig-3); two maps showing the species richness made with 0.5 degree (Fig-4) and 1 degree (Fig-5) grids, allow us to highlight the points of high species richness.

It should be noted that for lack of precise information on thier distribution, certain specimens or even certain species were not taken into account in the cartography; it is about Pavetta longistyla, Tricalysia fangana and Trichostachys interrupta. 
Hermann Taedoumg et al., Sch Acad J Biosci, Mar, 2021; 9(3): 68-83

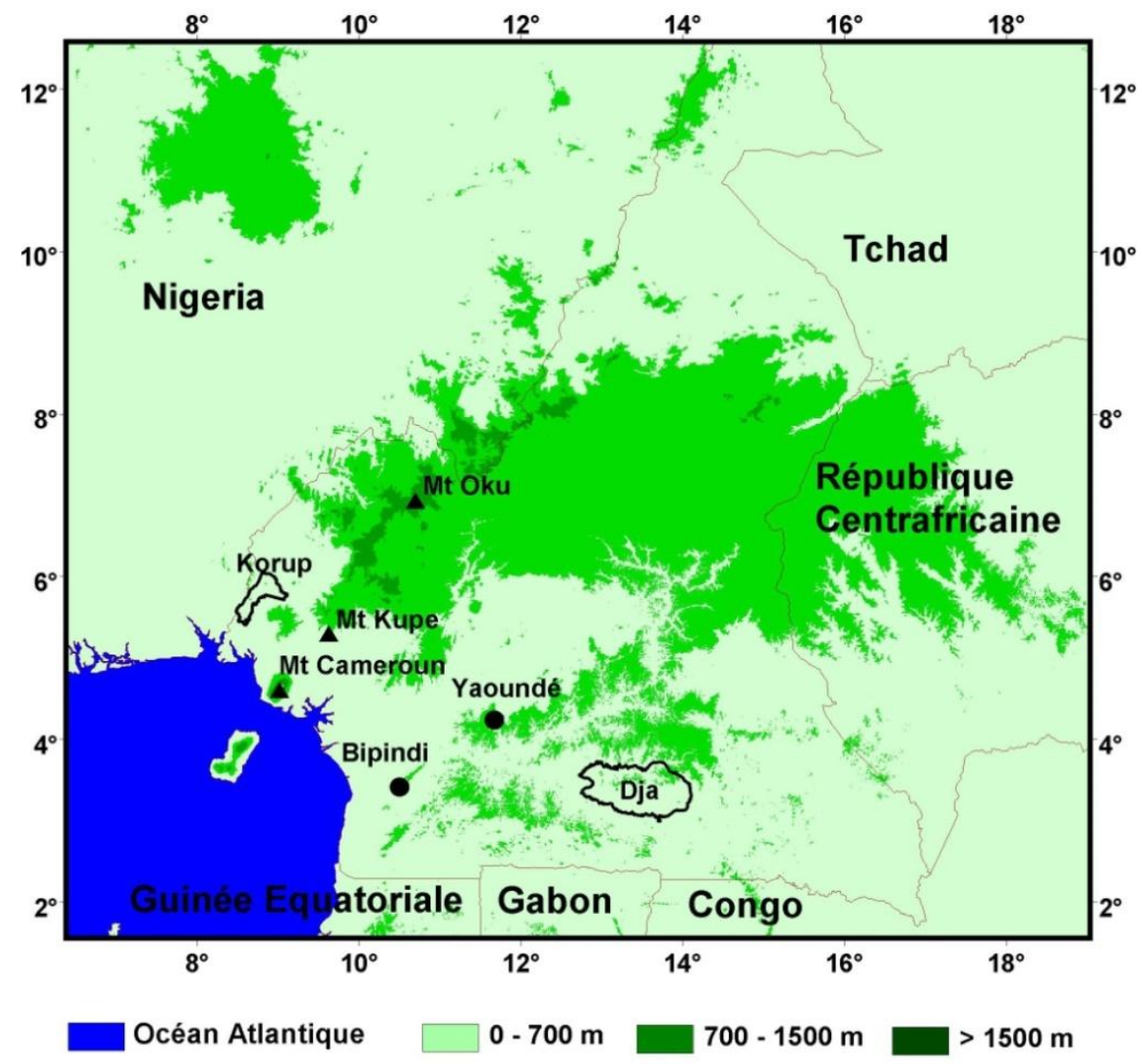

Fig-2: Topographic map of Cameroon

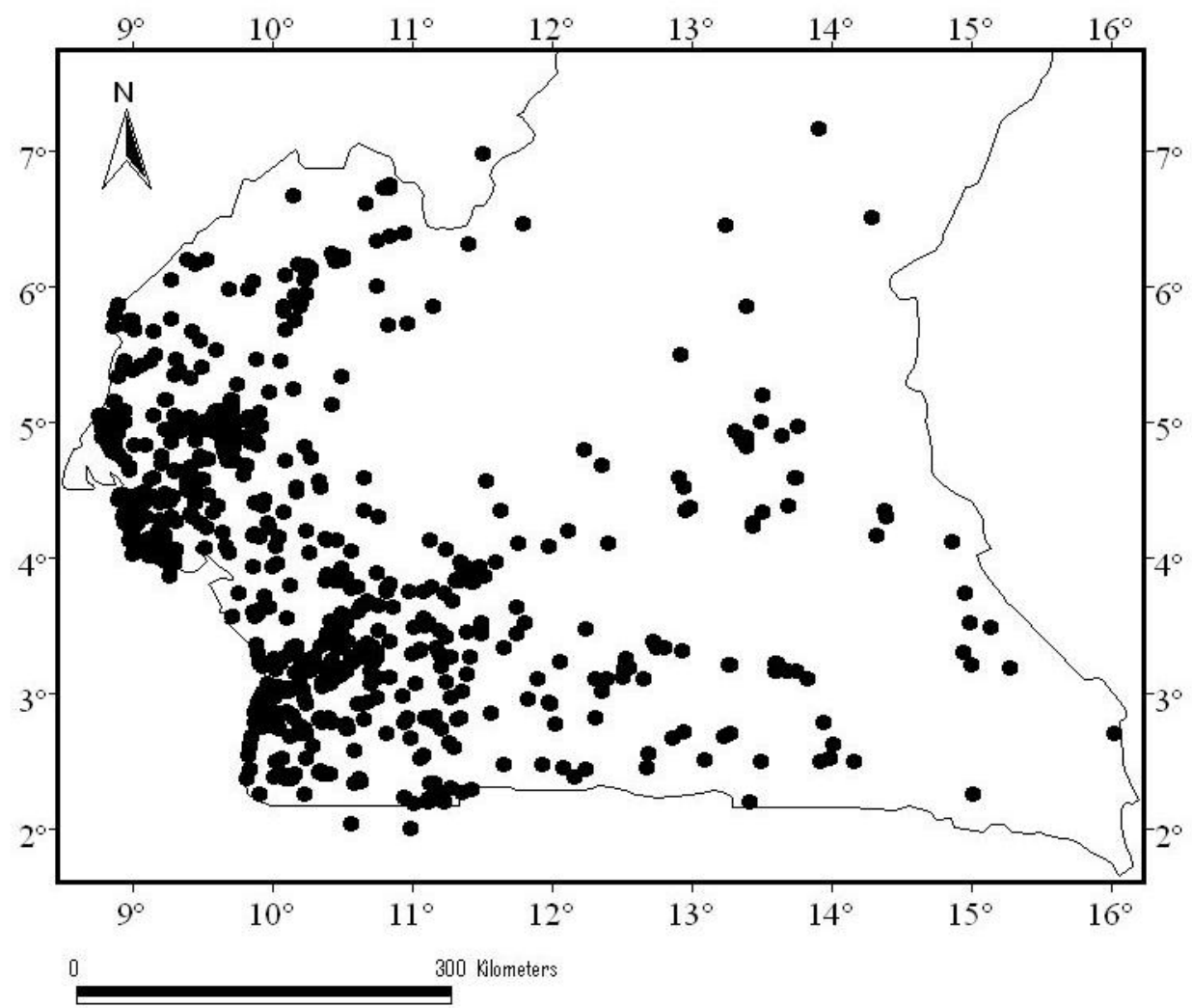

Fig-3: General distribution of Rubiaceae of the LGD present in Cameroon 


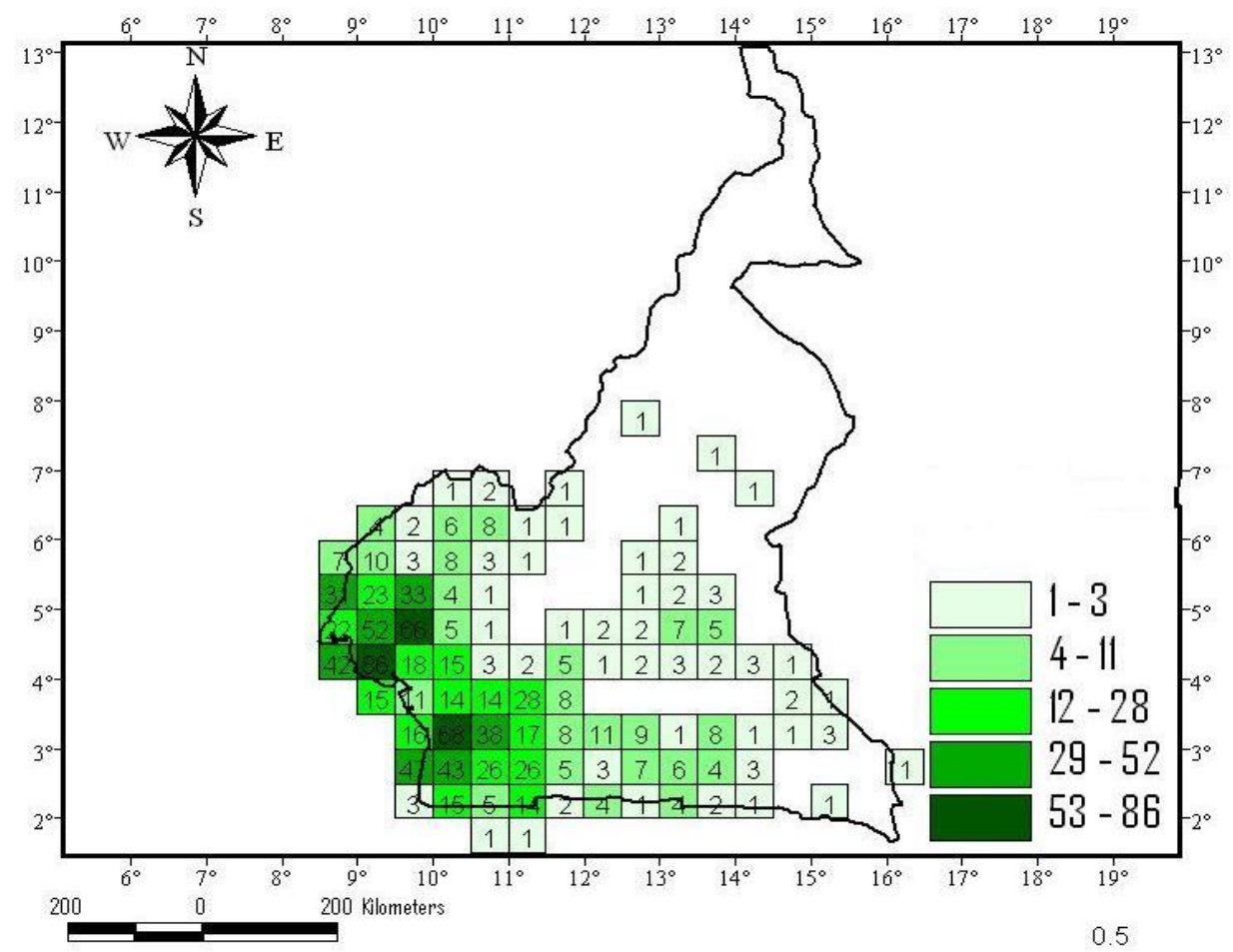

Fig-4: Species richness ( $0.5 \times 0.5$ degree grid cell) (numbers in the grid cells represent the number of species present)

The map with the 0.5 degree grid (Fig-4) shows quite clearly that medium and high altitude zones are the richest in endemic Rubiaceae. Four main zones stand out. One zone in Mount Cameroon (86 species), one in the Kupe and Bakossi Mountains (66 species), one in Bipindi and its surroundings (68 species), and one in the vicinity of Yaoundé (28 species).

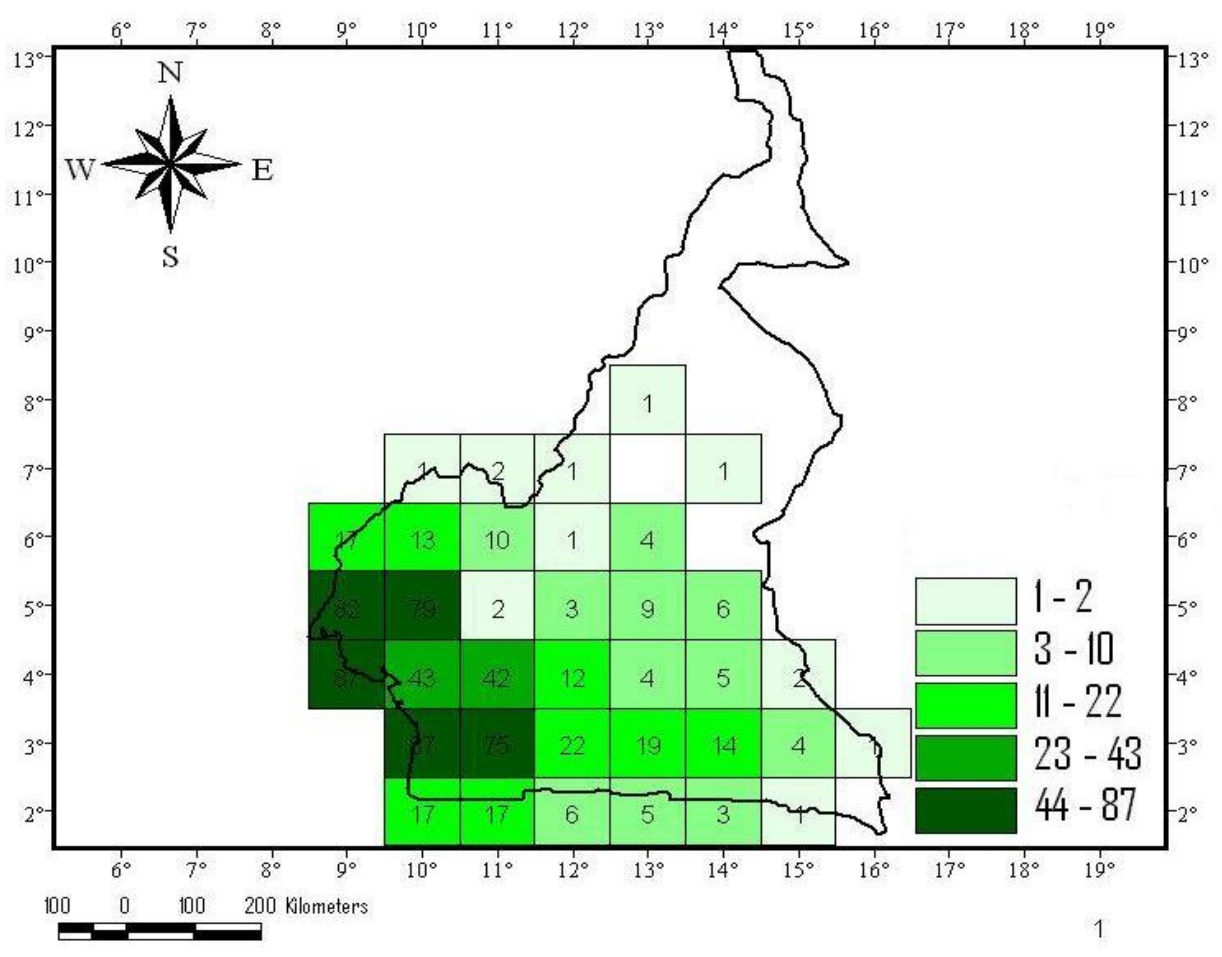

Fig-5: Species richness (1x1 degree grid cell) (numbers in the grid cells represent the number of species present) 
The map with the 1 degree grid (Fig-5) highlights the influence of the continental gradient on species richness. The coastal zone of Cameroon thus appears richer than the continental part.

It appears from the general distribution map and the species richness map that most of the Rubiaceae endemic to the LGD in Cameroon are found along a strip that corresponds to what Letouzey [21] calls the Biafran forests (including the coastal forests). This area, which extends along the coastal strip, is characterized by very high average annual rainfall.

\section{DISCUSSION}

With 288 LGD taxa recorded, Cameroon has the greatest specific richness; it is followed respectively by Gabon, south-eastern Nigeria, the islands of the Gulf of Guinea, Equatorial Guinea, Cabinda and Congo. Cameroon also stands out for its rate of endemism, which is much higher than that of the other countries in the area. Indeed, of the 387 taxa in the LGD, 148 are strictly endemic. Gabon follows with 61 taxa. The floristic similarity of Cameroon in Rubiaceae endemic to the LGD with Gabon could be explained by the existence of a strip of coastal forest (forest refuges) that extends from southern Cameroon, to Gabon and Equatorial Guinea [7]. Congo and Cabinda are on the fringe of the LGD, which is why they have the fewest species in common with Cameroon. On the other hand, Equatorial Guinea, which shares a border with Cameroon, has little floristic similarity with Cameroon. One would expect a higher similarity as is the case for Nigeria and Gabon. This is probably due to the poor knowledge of the flora of Equatorial Guinea.

The Rubiaceae reported from southeastern Nigeria are part of a large group that originates in Cameroon. This group extends from Port Harcourt in Nigeria, through Korup National Park and Mount Kupe to Mount Cameroon [22]. This may explain why Nigeria has only one species absent from Cameroon.

The low species richness of the other countries in the area is also due to the lack of extensive sampling. The lack of data on certain potentially very rich areas has often led to their erroneous characterization [23]. On the other hand, many new taxa have been discovered in Cameroon during the last decade. Indeed, of the 148 taxa of Rubiaceae endemic to Cameroon considered in this study, about 40 have been described recently [24-30, 1]. These taxa are generally immediately classified as endemic to Cameroon; while for some, future inventories in other countries in the domain could modify this status.

As for the distribution in Cameroon, the maps show the existence of several hotspots of Rubiaceae endemic to the area. The areas that are found to be rich are overlap on those previously located for Begonia [6,
7], for Rubiaceae [4], Robbrecht [31], for Orchidaceae [32].

However, it appears here that Yaoundé and its surroundings mentioned by Sonké et al., [4] as very rich, seem to be subject to discussion depending on the size of the grid cells. Indeed, the Yaoundé area shows a high species richness only on the 1 degree grid map. This region owes its richness to the mountains that surround it (Kala, Mbam-Minkom, Eloumden, Nkolbisson). The distance between these medium-altitude zones makes it difficult to highlight their richness on the maps, especially for those with small grids ( 0.5 degree $)$. On the other hand, these small grids are ideal for accurately delineating areas of high richness and endemism. It thus appears that the species richness attributed to an area depends closely on the size of the grids chosen; in fact, a small grid will highlight areas of high species richness and/or endemism on small surfaces that often fit within a single grid. A large grid size can make some information incorrect because it can put together species that in reality are not.

Several studies have described Mount Cameroon and its surroundings as one of the most important hotspots in sub-Saharan Africa for Rubiaceae and other taxonomic groups [12, 7, 33, 22, 31]. However, the Bipindi region and its surroundings have a specific and even generic richness of Rubiaceae that is almost equal to Mount Cameroon; an observation already made by Droissart et al., [32] with the Orchidaceae family.

It also appears that the Biafran forests and the forests of the sub-montane level contain almost all the Rubiaceae endemic to Cameroon, with a large proportion of species known from a single locality. These localities correspond for the most part to the medium-altitude massifs of southern Cameroon (Bipindi and Akom II massif) and the southwest (Bakossi and Kupe massifs). The medium-altitude zones around Yaoundé also show a fairly interesting richness. The main factor explaining the variations in species richness of endemic Rubiaceae seems to be altitude. Spatial heterogeneity due to the relief (mountains) induces the establishment of numerous habitats with limited surfaces; this, associated with favorable climatic conditions, sets up important speciation mechanisms [33]. Thus, the more complex the relief of an area, the higher its specific richness will be.

Speciation alone, however, cannot explain the endemism and species richness of these areas. In sub-Saharan Africa, there is a strong correlation between centers of endemism and areas of high diversity. The theory of forest refuges from the last ice age may allow us to justify the endemism of the above-mentioned areas of high diversity. 
The continental gradient also seems to have played a significant role in the endemism, species richness, and distribution of endemic Rubiaceae in Cameroon. The species richness decreases considerably with the increase in longitude and therefore with the distance from the ocean. Thus, the richness decreases from the Atlantic forests along the coastal strip to the Congolese forests, passing through the deciduous forests. This is probably explained by the decrease in annual rainfall along the same gradient. The high rainfall could therefore also justify the endemicity of these hotspots.

The species richness also depends on the intensity of sampling. In fact, the region located more to the east of Cameroon seems to suffer from a lack of surveys, and the same is true for the continental part of Equatorial Guinea. This raises the inevitable question: are the zones of great specific richness are they really rich or simply more prospected than others? Otherwise, what is the impact of oversampling on the species richness of an area?

\section{CONCLUSION}

The LGD has 387 endemic Rubiaceae taxa. Cameroon, in addition to its central geographical position in the LGD, also occupies a central position in terms of specific richness and rate of endemism. One hundred and forty eight taxa are exclusive to Cameroon. However, it should be noted that vast areas in Cameroon as well as in other countries are still very low inventoried. Despite all, the present study confirms that Cameroon has one of the most remarkable species richness in sub-Saharan Africa.

Altitude appears to be the main factor that explains the fluctuations in species richness. The establishment of endemic areas and therefore of species richness is the result of several factors more or less related to altitude. But other factors such as speciation and the continental gradient also contribute to explain these fluctuations.

Study of the diversity and distribution of Rubiaceae endemic to the LGD in Cameroon reveals four main areas of high diversity. The first one is located in Mount Cameroon and its surroundings, the second one is located in the mountainous massifs around Bipindi and
Akom II, the third one is located in Mount Kupe and Bakossi, and the last one is of lesser importance in the hills around Yaoundé.

Areas around Yaoundé and the massifs around Bipindi have no conservation status. Both areas are under permanent threat from logging and slash-and-burn agriculture and from ever-increasing population pressures. There is an urgent need for conservation measures to be taken to protect these forests, the importance of which is highlighted in this study. The city of Yaounde is a large urban agglomeration and the easily accessible hills could in the medium term be financially viable through ecotourism.

This study proved that Rubiaceae could be effectively used as bioindicators for the identification of high biodiversity areas without conducting exhaustive inventories. However, it is clear that there are many gaps in data collection. This is true for Rubiaceae as well as for other taxonomic groups.

Throughout this analysis, areas of high species richness were by inference considered as areas of endemism. The use of tools that allow the location of these areas independently of species richness would be welcome. Allusion is made here to PAE (Parsimony Analysis of Endemicity) which is a method for generating cladograms directly from species distribution data.

Additional inventories should focus on areas in east Cameroon and in the other LGD countries, especially in the mainland of Equatorial Guinea. In addition, taxonomic research efforts are needed for the large number of species that have no herbarium specimens available.

Other taxonomic groups of great numerical importance (Asteraceae, Fabaceae etc.) should be used in order to delimit more precisely these areas.

\section{ACKNOWLEDGEMENTS}

The authors are grateful to the curators and staff of the Herbaria of Yaounde and Limbe for giving them access to to their materials and logistics. They also want to thank the two anonymous reviewers for their useful comments and suggestions 


\section{ANNEXES}

List of Rubiaceae endemic to the LGD and their distribution

(Numbers in the table: $1=$ présence; $0=$ absence. Cam $=$ Cameroun, Gab $=$ Gabon, Con $=$ Congo, GEq $=$ Equatorial Guinea, $\mathrm{Cab}=$ Cabinda, Nig = Nigeria, $\mathrm{GG}=$ the islands of the Gulf of Guinea)

\begin{tabular}{|c|c|c|c|c|c|c|c|c|}
\hline Genus & Species & छే & है & ¿ & ช્| & छै & $\stackrel{000}{Z}$ & 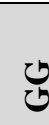 \\
\hline \multirow[t]{2}{*}{ Aidia } & Aidia rhacodesepala (K. Schum.) E. M. A. Petit & 1 & 0 & 0 & 0 & 0 & 0 & 0 \\
\hline & Aidia rubens (Hiern) G. Taylor & 1 & 1 & 0 & 0 & 1 & 0 & 0 \\
\hline Anthospermum & Anthospermum asperuloides Hook. f. & 1 & 0 & 0 & 0 & 0 & 0 & 1 \\
\hline Atractogyne & Atractogyne batesii Wernham & 1 & 0 & 0 & 0 & 0 & 0 & 0 \\
\hline Aoranthe & Aoranthe annulata (K. Schum.) Somers & 0 & 1 & 0 & 0 & 0 & 0 & 0 \\
\hline \multirow[t]{6}{*}{ Aulacocalyx } & Aulacocalyx camerooniana Sonké \& S. E. Dawson & 1 & 0 & 0 & 0 & 0 & 0 & 0 \\
\hline & Aulacocalyx caudata (Hiern) Keay & 1 & 1 & 0 & 1 & 0 & 1 & 0 \\
\hline & Aulacocalyx lamprophylla K. Krause & 1 & 0 & 0 & 0 & 0 & 0 & 0 \\
\hline & Aulacocalyx mapiana Sonké \& Bridson & 1 & 0 & 0 & 0 & 0 & 0 & 0 \\
\hline & Aulacocalyx subulata (N. Hallé) Figueiredo & 0 & 1 & 0 & 0 & 0 & 0 & 0 \\
\hline & Aulacocalyx talbotii (Wernham) Keay & 1 & 1 & 0 & 0 & 0 & 1 & 0 \\
\hline \multirow[t]{3}{*}{ Belonophora } & Belonophora ongensis S. E. Dawson \& Cheek & 1 & 1 & 0 & 0 & 0 & 0 & 0 \\
\hline & Belonophora talbotii (Wernham) Keay & 1 & 0 & 0 & 0 & 0 & 1 & 0 \\
\hline & Belonophora werhamii Hutch. \& Dalziel & 1 & 0 & 0 & 0 & 0 & 1 & 0 \\
\hline \multirow[t]{11}{*}{ Bertiera } & Bertiera artistipula N. Hallé & 0 & 1 & 0 & 0 & 0 & 0 & 0 \\
\hline & Bertiera elabensis $\mathrm{K}$. Krause & 1 & 1 & 0 & 1 & 0 & 0 & 0 \\
\hline & Bertiera heterophylla Nguembou \& Sonké & 1 & 1 & 0 & 0 & 0 & 0 & 0 \\
\hline & Bertiera lanx N. Hallé & 0 & 1 & 0 & 0 & 0 & 0 & 0 \\
\hline & Bertiera laxa var. bamendae Hepper & 1 & 0 & 0 & 0 & 0 & 0 & 0 \\
\hline & Bertiera laxissima K. Schum. & 1 & 0 & 0 & 0 & 0 & 0 & 0 \\
\hline & Bertiera ledremannii $\mathrm{K}$. Krause & 1 & 0 & 0 & 0 & 0 & 0 & 0 \\
\hline & Bertiera longiloba $\mathrm{K}$. Krause & 1 & 0 & 0 & 0 & 0 & 0 & 0 \\
\hline & Bertiera retrofracta $\mathrm{K}$. Schum. & 1 & 0 & 0 & 1 & 0 & 1 & 1 \\
\hline & Bertiera rosseeliana Sonké, Essono \&A.P. Davis & 1 & 0 & 0 & 1 & 0 & 0 & 0 \\
\hline & Bertiera thollonii De Wild. \& T.Durand & 0 & 0 & 1 & 0 & 0 & 0 & 0 \\
\hline Calochone & Calochone acuminata Keay & 1 & 1 & 0 & 0 & 1 & 0 & 0 \\
\hline Calycosiphonia & Calycosiphonia uniflora (inédit) & 1 & 0 & 0 & 0 & 0 & 0 & 0 \\
\hline \multirow[t]{7}{*}{ Chassalia } & Chassalia Bipindensis Sonké, Nguembou \& A.P. Davis & 1 & 0 & 0 & 0 & 0 & 0 & 0 \\
\hline & Chassalia cupularis Hutch. \& Dalziel & 1 & 0 & 0 & 0 & 0 & 1 & 0 \\
\hline & Chassalis laikomensis Cheek & 1 & 0 & 0 & 0 & 0 & 0 & 0 \\
\hline & Chassalia pteropetala (K. Schum.) Cheek & 1 & 0 & 0 & 0 & 0 & 0 & 0 \\
\hline & chassalia simplex $\mathrm{K}$. Krause & 1 & 0 & 0 & 0 & 0 & 0 & 0 \\
\hline & Chassalia subspicata K. Schum. & 1 & 0 & 0 & 0 & 0 & 0 & 0 \\
\hline & Chassalia zenkeri K. Schum. \& K. Krause & 1 & 0 & 0 & 0 & 0 & 1 & 0 \\
\hline \multirow[t]{8}{*}{ Chazaliella } & Chazaliellia insidens $\mathrm{ssp}$. Insidens & 1 & 0 & 0 & 1 & 0 & 0 & 1 \\
\hline & Chazaliellia letouzeyi Robbr. & 1 & 1 & 0 & 0 & 0 & 0 & 0 \\
\hline & Chazaliella obanensis (Wernham) E. M. A. Petit \& Verdc. & 1 & 0 & 0 & 0 & 0 & 1 & 0 \\
\hline & Chazaliella obovoidea ssp. Villostipula Verdc. & 1 & 0 & 1 & 0 & 0 & 0 & 0 \\
\hline & Chazaliella oddonii var. cameroonensis Verdc. & 1 & 0 & 0 & 0 & 0 & 1 & 0 \\
\hline & Chazaliella parviflora (R. D. Good) Verdc. & 0 & 1 & 0 & 0 & 1 & 0 & 0 \\
\hline & Chazaliella rotundifolia (R. D. Good) E. M. A. Petit \& Verdc. & 0 & 1 & 0 & 0 & 1 & 0 & 0 \\
\hline & Chazaliella viridicalyx (R. D. Good) Verdc. & 1 & 0 & 0 & 0 & 1 & 0 & 0 \\
\hline \multirow[t]{7}{*}{ Coffea } & Coffea bakossii Cheek \& Bridson & 1 & 0 & 0 & 0 & 0 & 0 & 0 \\
\hline & Coffea fotsoana Stoff. \& Sonké & 1 & 0 & 0 & 0 & 0 & 0 & 0 \\
\hline & Coffea heterocalyx Stoff. & 1 & 0 & 0 & 0 & 0 & 0 & 0 \\
\hline & Coffea leonimontana Stoff. & 1 & 0 & 0 & 0 & 0 & 0 & 0 \\
\hline & Coffea magnistipula Stoff. \& Robbr. & 1 & 1 & 0 & 0 & 0 & 0 & 0 \\
\hline & Coffea mapiana Sonké, Nguembou \& A.P. Davis & 1 & 0 & 0 & 0 & 0 & 0 & 0 \\
\hline & Coffea montekupensis Stoff. & 1 & 0 & 0 & 0 & 0 & 0 & 0 \\
\hline Coleactina & Coleactina papalis N. Hallé & 0 & 1 & 0 & 0 & 0 & 0 & 0 \\
\hline Corynanthe & Corynanthe mayumbensis (R. D. Good) N. Hallé & 0 & 1 & 0 & 0 & 1 & 0 & 0 \\
\hline \multirow[t]{3}{*}{ Craterispermum } & Craterispermum aristatum Wernham & 1 & 0 & 0 & 0 & 0 & 1 & 0 \\
\hline & $\begin{array}{l}\text { Craterispermum inquisitorium var. longipedunculatum R. D. } \\
\text { Good }\end{array}$ & 0 & 1 & 0 & 0 & 1 & 0 & 0 \\
\hline & Craterispermum deblockianum Taedoumg \& Hamon & 0 & 1 & 0 & 0 & 0 & 0 & 0 \\
\hline \multicolumn{8}{|c|}{ (C) 2021 Scholars Academic Journal of Biosciences | Published by SAS Publishers, India } & 76 \\
\hline
\end{tabular}


Hermann Taedoumg et al., Sch Acad J Biosci, Mar, 2021; 9(3): 68-83

\begin{tabular}{|c|c|c|c|c|c|c|c|c|}
\hline Genus & Species & छ & है & ¿ี & ช્ & है & $\stackrel{000}{Z}$ & ن \\
\hline & Craterispermum gabonicum Taedoumg \& De Block & 0 & 1 & 0 & 0 & 0 & 0 & 0 \\
\hline & Craterispermum ledermannii $\mathrm{K}$. Krause & 1 & 0 & 0 & 1 & 0 & 0 & 0 \\
\hline & Craterispermum parvifolium Taedoumg \& Sonké & 1 & 1 & 0 & 1 & 0 & 0 & 0 \\
\hline & Craterispermum robbrechtianum Taedoumg \& Sonké & 1 & 1 & 0 & 0 & 0 & 0 & 0 \\
\hline & Craterispermum rumpianum Taedoumg \& Hamon & 1 & 0 & 0 & 0 & 0 & 0 & 0 \\
\hline & Craterispermum sonkeanum Taedoumg \& Hamon & 0 & 1 & 0 & 1 & 0 & 0 & 0 \\
\hline Cremaspora & Cremaspora thomsonii Hiern & 1 & 0 & 0 & 0 & 0 & 1 & 0 \\
\hline \multirow[t]{10}{*}{ Cuviera } & Cuviera calycosa Wernham & 1 & 1 & 0 & 0 & 0 & 1 & 0 \\
\hline & Cuviera heisteriifolia Mildbr. & 1 & 0 & 0 & 0 & 0 & 0 & 0 \\
\hline & Cuviera ledermannii $\mathrm{K}$. Krause & 1 & 0 & 0 & 0 & 0 & 0 & 0 \\
\hline & Cuviera leniochlamys K. Schum. & 1 & 0 & 0 & 0 & 0 & 0 & 0 \\
\hline & Cuviera physinodes K. Schum & 0 & 1 & 0 & 0 & 0 & 0 & 0 \\
\hline & Cuviera pierrei $\mathrm{N}$. Hallé & 0 & 1 & 0 & 0 & 0 & 0 & 0 \\
\hline & Cuviera talbotii (Wernham) Verdc. & 1 & 0 & 0 & 0 & 0 & 1 & 0 \\
\hline & Cuviera trilocularis Hiern & 1 & 0 & 0 & 0 & 0 & 1 & 0 \\
\hline & Cuviera truncata Hutch. \& Dalziel & 1 & 0 & 0 & 0 & 0 & 1 & 0 \\
\hline & Cuviera wernhamii Cheek in S. Cable \& M. Cheek & 1 & 0 & 0 & 0 & 0 & 1 & 0 \\
\hline Didymosalpinx & Didymosalpinx konguensis (Hiern) Keay & 0 & 0 & 0 & 1 & 0 & 0 & 0 \\
\hline \multirow[t]{3}{*}{ Ecpoma } & Ecpoma apocynacea K. Schum. & 1 & 0 & 0 & 0 & 0 & 0 & 0 \\
\hline & Ecpoma geantha (Hiern) N. Hallé & 0 & 1 & 0 & 0 & 0 & 0 & 0 \\
\hline & Ecpoma hierniana (Wernham) N. Hallé \& F. Hallé & 1 & 1 & 0 & 0 & 0 & 0 & 0 \\
\hline Euclinia & Euclinia squamifera (R. D. Good) Keay & 1 & 1 & 0 & 0 & 0 & 0 & 0 \\
\hline Fagodia & Fagodia cinerascens Robyns & 1 & 0 & 0 & $1 ?$ & 0 & 0 & 0 \\
\hline \multirow[t]{6}{*}{ Gaertnera } & Gaertnera dinklagei K. Schum. & 1 & 1 & 0 & 0 & 0 & 0 & 0 \\
\hline & Gaertnera fissistipula (K. Schum. \& K. Krause) E. M. A. Petit & 1 & 0 & 0 & 0 & 0 & 0 & 0 \\
\hline & Gaertnera salicifolia C.H.Wright ex Baker & 0 & 1 & 0 & 0 & 0 & 0 & 0 \\
\hline & Gaertnera spicata K. Schum. & 0 & 1 & 0 & 0 & 0 & 0 & 0 \\
\hline & Gaertnera stictophylla (Hiern) E. M. A. Petit & 0 & 1 & 0 & 0 & 0 & 0 & 0 \\
\hline & Gaertnera trachystyla (Hiern) E. M. A. Petit & 1 & 1 & 0 & 0 & 0 & 0 & 0 \\
\hline Galium & Galium deistelii K. Krause & 1 & 0 & 0 & 0 & 0 & 0 & 0 \\
\hline \multirow[t]{4}{*}{ Geophila } & Geophila aschersoniana Büttner & 0 & 0 & 1 & 0 & 0 & 0 & 0 \\
\hline & Geophila emarginata K. Krause & 1 & 0 & 0 & 0 & 0 & 0 & 0 \\
\hline & Geophila lancistipula Hiern & 1 & 1 & 0 & 0 & 0 & 1 & 0 \\
\hline & Geophila speciosa K. Schum. & 1 & 0 & 0 & 0 & 0 & 0 & 0 \\
\hline Heinsia & Heinsia myrmoecia (K. Schum.) N. Hallé & 1 & 0 & 0 & 0 & 0 & 0 & 0 \\
\hline Hekistocarpa & Hekistocarpa minutiflora Hook. f. & 1 & 0 & 0 & 0 & 0 & 1 & 0 \\
\hline \multirow[t]{3}{*}{ Hymenocoleus } & Hymenocoleus glaber Robbr. & 1 & 0 & 0 & 0 & 0 & 0 & 0 \\
\hline & Hymenocoleus globulifer Robbr. & 1 & 1 & 1 & 1 & 0 & 0 & 0 \\
\hline & Hymenocoleus nervopilosus var. orientalis Robbr. & 1 & 1 & 0 & 0 & 0 & 0 & 0 \\
\hline \multirow[t]{4}{*}{ Hymenodyction } & Hymenodictyon biafranum Hiern & 1 & 1 & 0 & 0 & 0 & 1 & 1 \\
\hline & Hymenodictyon bracteatum K. Schum. & 1 & 0 & 0 & 0 & 0 & 0 & 0 \\
\hline & Hymenodictyon epidendron Mildbr. ex Hutch. \& Dalziel & 0 & 0 & 0 & 0 & 0 & 0 & 1 \\
\hline & Hymenodictyon oreophyton Hoyle & 1 & 0 & 0 & 0 & 0 & 0 & 0 \\
\hline \multirow[t]{12}{*}{ Ixora } & Ixora aneimenodesma ssp. Aneimenodesma & 1 & 1 & 0 & 0 & 0 & 0 & 0 \\
\hline & Ixora banjoana $\mathrm{K}$. Krause & 1 & 0 & 0 & 0 & 0 & 0 & 0 \\
\hline & Ixora batesii Wernham & 1 & 0 & 0 & 0 & 0 & 0 & 0 \\
\hline & Ixora delicatula Keay & 1 & 0 & 0 & 0 & 0 & 1 & 0 \\
\hline & Ixora euosmia K. Schum. & 1 & 0 & 0 & 0 & 0 & 1 & 0 \\
\hline & Ixora foliosa Hiern & 1 & 0 & 0 & 0 & 0 & 1 & 0 \\
\hline & Ixora hippoperifera Bremek. & 1 & 1 & 0 & 0 & 0 & 1 & 0 \\
\hline & Ixora inundata Hiern & 1 & 1 & 0 & 1 & 0 & 0 & 0 \\
\hline & Ixora ledermannii $\mathrm{K}$. Krause & 1 & 0 & 0 & 0 & 0 & 0 & 0 \\
\hline & Ixora minutiflora Hiern & 1 & 1 & 1 & 0 & 0 & 1 & 0 \\
\hline & Ixora nematopoda K. Schum. & 1 & 1 & 1 & 0 & 1 & 0 & 1 \\
\hline & Ixora synactica De Block & 1 & 0 & 0 & 0 & 0 & 0 & 0 \\
\hline \multirow[t]{2}{*}{ Lasianthus } & Lasianthus longipes K. Krause & 1 & 0 & 0 & 0 & 0 & 0 & 0 \\
\hline & Lasianthus urophylloides Good & 0 & 0 & 0 & 0 & 1 & 0 & 0 \\
\hline \multirow[t]{3}{*}{ Leptactina } & Leptactina latifolia K. Schum. & 1 & 1 & 0 & 0 & 0 & 0 & 0 \\
\hline & Leptactina mannii Hook. f. & 1 & 1 & 0 & 0 & 0 & 0 & 0 \\
\hline & Leptactina polyneura $\mathrm{K}$. Krause & 0 & 0 & 0 & 1 & 0 & 0 & 0 \\
\hline
\end{tabular}


Hermann Taedoumg et al., Sch Acad J Biosci, Mar, 2021; 9(3): 68-83

\begin{tabular}{|c|c|c|c|c|c|c|c|c|}
\hline Genus & Species & छ & है & ¿ี & ช્ & है & $\stackrel{000}{Z}$ & ن \\
\hline & Leptactina rheophytica Sonké \& Neuba & 0 & 1 & 0 & 0 & 0 & 0 & 0 \\
\hline & Leptactina tessmannii $\mathrm{K}$. Krause & 0 & 0 & 0 & 1 & 0 & 0 & 0 \\
\hline Mitriostigma & Mitriostigma barteri Hook. f. ex Hiern & 1 & 0 & 0 & 0 & 0 & 0 & 1 \\
\hline Morinda & Morinda batesii Wernham & 1 & 0 & 0 & 0 & 0 & 0 & 0 \\
\hline \multirow[t]{9}{*}{ Mussaenda } & Mussaenda bityensis Wernham & 1 & 0 & 0 & 0 & 0 & 0 & 0 \\
\hline & Mussaenda lancifolia $\mathrm{K}$. Krause & 0 & 0 & 0 & 0 & 0 & 0 & 1 \\
\hline & Mussaenda leptantha Wernham & 1 & 0 & 0 & 0 & 0 & 0 & 0 \\
\hline & Mussaenda macrosiphon Wernham & 0 & 1 & 0 & 0 & 0 & 0 & 0 \\
\hline & Mussaenda nijensis Good & 0 & 1 & 0 & 0 & 0 & 0 & 0 \\
\hline & Mussaenda polita Hiern & 1 & 1 & 0 & 1 & 0 & 1 & 1 \\
\hline & Mussaenda soyauxii Büttner & 1 & 1 & 0 & 0 & 0 & 0 & 0 \\
\hline & Mussaenda tenuiflora var. principensis G. Taylor & 0 & 0 & 0 & 0 & 0 & 0 & 1 \\
\hline & Mussaenda tenuiflora var. thomensis G. Taylor & 0 & 0 & 0 & 0 & 0 & 0 & 1 \\
\hline \multirow{9}{*}{ Oxyanthus } & Oxyanthus barensis K. Krause & 1 & 0 & 0 & 0 & 0 & 0 & 0 \\
\hline & Oxyanthus laxiflorus K. Schum. ex Hutch. \& Dalziel & 1 & 1 & 0 & 0 & 0 & 1 & 1 \\
\hline & Oxyanthus ledermannii K. Krause & 1 & 0 & 0 & 0 & 0 & 0 & 0 \\
\hline & Oxaynthus maymbensis Good & 0 & $1 ?$ & 0 & 0 & 1 & 0 & 0 \\
\hline & Oxyanthus montanus Sonké & 1 & 0 & 0 & 0 & 0 & 0 & 1 \\
\hline & Oxyanthus nangensis K. Krause & 1 & 0 & 0 & 0 & 0 & 0 & 0 \\
\hline & Oxyanthus okuensis Cheek \& Sonké & 1 & 0 & 0 & 0 & 0 & 0 & 0 \\
\hline & Oxyanthus oliganthus K. Schum. & 1 & 0 & 0 & 0 & 0 & 0 & 0 \\
\hline & Oxyanthus pulcher K. Schum. & 1 & 0 & 0 & 0 & 0 & 0 & 0 \\
\hline \multirow{12}{*}{ Pauridiantha } & Pauridiantha bulocularis Bremek. & 0 & 0 & 0 & 0 & 1 & 0 & 0 \\
\hline & Pauridiantha canthiiflora Hook. f. & 1 & 1 & 0 & 1 & 0 & 1 & 1 \\
\hline & Pauridiantha divaricata (K. Schum.) Bremek. & 1 & 0 & 0 & 0 & 0 & 0 & 0 \\
\hline & Pauridiantha efferata N. Hallé & 1 & 1 & 0 & 0 & 0 & 0 & 0 \\
\hline & Pauridiantha letestuana (N. Hallé) Ntore \& Dessein & 0 & 1 & 0 & 0 & 0 & 0 & 0 \\
\hline & Pauridiantha micrantha Bremek. & 0 & 1 & 0 & 0 & 0 & 0 & 0 \\
\hline & Pauridiantha microphylla R. D. Good & 0 & 1 & 0 & 0 & 0 & 0 & 0 \\
\hline & Pauridiantha multiflora K. Schum. & 1 & 0 & 0 & 0 & 0 & 0 & 0 \\
\hline & Pauridiantha pierlotii N. Hallé & 0 & 0 & 1 & 0 & 0 & 0 & 0 \\
\hline & Pauridiantha pleiantha Ntore \& Dessein & 0 & 1 & 0 & 0 & 0 & 0 & 0 \\
\hline & Pauridiantha smetsiana Ntore \& Dessein & 0 & 1 & 0 & 0 & 0 & 0 & 0 \\
\hline & Pauridiantha venusta N. Hallé & 1 & 1 & 0 & 0 & 0 & 0 & 0 \\
\hline \multirow{3}{*}{ Pausinytalia } & Pausinystalia brachythyrsum (K. Schum.) W.Brandt & 1 & 0 & 0 & 0 & 0 & 0 & 0 \\
\hline & Pausinystalia johimbe (K. Schum.) Pierre ex Beille & 1 & 1 & 0 & 1 & 0 & 1 & 0 \\
\hline & Pausinystalia talbotii Wernham & 1 & 0 & 0 & 0 & 0 & 1 & 0 \\
\hline \multirow[t]{23}{*}{ Pavetta } & Pavetta annobonensis Bremek. & 0 & 0 & 0 & 0 & 0 & 0 & 1 \\
\hline & Pavetta antennifera Wernham & 1 & 0 & 0 & 0 & 0 & 0 & 0 \\
\hline & Pavetta baconiella Bremek. & 1 & 0 & 0 & 0 & 0 & 0 & 0 \\
\hline & Pavetta bangweensis Bremek. & 1 & 0 & 0 & 0 & 0 & 0 & 0 \\
\hline & Pavatta batesiana Bremek. & 1 & 0 & 0 & 0 & 0 & 0 & 0 \\
\hline & Pavetta bidentata var sessilifolia S. D. Manning & 1 & 0 & 0 & 0 & 0 & 0 & 0 \\
\hline & Pavetta brachycalyx Hiern & 1 & 0 & 0 & 0 & 0 & 0 & 0 \\
\hline & Pavetta brachysiphon Bremek. & 1 & 0 & 0 & 0 & 0 & 0 & 0 \\
\hline & Pavetta camerounensis ssp. Brevirama S. D. Manning & 1 & 0 & 0 & 0 & 0 & 0 & 0 \\
\hline & Pavetta camerounensis ssp. Camerounensis & 1 & 0 & 0 & 1 & 0 & 0 & 0 \\
\hline & Pavetta dermatophylla Mildbr. & 0 & 0 & 0 & 0 & 0 & 0 & 1 \\
\hline & Pavetta gabonica Bremek. & 1 & 1 & 0 & 0 & 0 & 0 & 0 \\
\hline & Pavetta gracilipes Hiern & 1 & 1 & 1 & 0 & 0 & 0 & 0 \\
\hline & Pavetta grossissima S. D. Manning & 1 & 0 & 0 & 0 & 0 & 0 & 0 \\
\hline & Pavetta hierniana Bremek. & 1 & 1 & 0 & 0 & 0 & 1 & 0 \\
\hline & Pavetta hispida Hiern & 1 & 1 & 0 & 0 & 1 & 1 & 1 \\
\hline & Pavetta hookeriana var. hookeriana & 1 & 0 & 0 & 0 & 0 & 1 & 1 \\
\hline & Pavetta hookeriana var. pubinervata S. D. Manning & 1 & 0 & 0 & 0 & 0 & 0 & 0 \\
\hline & Pavetta kribiensis S. D. Manning & 1 & 0 & 0 & 0 & 0 & 0 & 0 \\
\hline & Pavetta kupensis S. D. Manning & 1 & 0 & 0 & 0 & 0 & 0 & 0 \\
\hline & Pavetta laxa S. D. Manning & 1 & 0 & 0 & 0 & 0 & 0 & 0 \\
\hline & Pavetta longibrachiata Bremek. & 1 & 0 & 0 & 0 & 0 & 0 & 0 \\
\hline & Pavetta longistyla S. D. Manning & 1 & 0 & 0 & 0 & 0 & 0 & 0 \\
\hline
\end{tabular}


Hermann Taedoumg et al., Sch Acad J Biosci, Mar, 2021; 9(3): 68-83

\begin{tabular}{|c|c|c|c|c|c|c|c|c|}
\hline Genus & Species & छే & है & ฮี & 秀 & లి & $i_{Z}^{000}$ & பّ \\
\hline & Pavetta macrostemon K. Schum. & 1 & 0 & 0 & 0 & 0 & 0 & 0 \\
\hline & Pavetta mpomii S. D. Manning & 1 & 0 & 0 & 0 & 0 & 0 & 0 \\
\hline & Pavetta muiriana S. D. Manning & 1 & 0 & 0 & 0 & 0 & 0 & 0 \\
\hline & Pavetta namatae S. D. Manning & 1 & 0 & 0 & 0 & 0 & 0 & 0 \\
\hline & Pavetta neurocarpa Benth & 1 & 0 & 0 & 0 & 0 & 1 & 1 \\
\hline & Pavetta ombrophila Bremek. & 1 & 0 & 0 & 0 & 0 & 0 & 0 \\
\hline & Pavetta oresitropha Bremek. & 0 & 0 & 0 & 0 & 0 & 0 & 1 \\
\hline & Pavetta owariensis var. glaucescens (Hiern) S. D. Manning & 1 & 1 & 1 & 1 & 1 & 1 & 1 \\
\hline & Pavetta owariensis var. opaca S. D. Manning & 1 & 0 & 0 & 0 & 0 & 0 & 0 \\
\hline & Pavetta owariensis var. satabiei S. D. Manning & 1 & 0 & 0 & 0 & 0 & 0 & 0 \\
\hline & Pavetta plumosa Hutch. \& Dalziel & 1 & 0 & 0 & 0 & 0 & 0 & 0 \\
\hline & Pavetta renidens (K. Krause) Bremek. & 1 & 0 & 0 & 0 & 0 & 0 & 0 \\
\hline & Pavetta rigida Hiern & 1 & 0 & 0 & 0 & 0 & 1 & 1 \\
\hline & Pavetta robusta Bremek. & 1 & 1 & 0 & 0 & 0 & 0 & 0 \\
\hline & Pavetta rubentifolia S. D. Manning & 1 & 0 & 0 & 0 & 0 & 0 & 0 \\
\hline & Pavetta staudtii Hutch. \& Dalziel & 1 & 0 & 0 & 0 & 0 & 0 & 0 \\
\hline & Pavetta stemonogyne Mildbr. ex Bremek. & 1 & 0 & 0 & 0 & 0 & 0 & 0 \\
\hline & Pavetta tenuissima S. D. Manning & 1 & 0 & 0 & 1 & 0 & 0 & 0 \\
\hline & Pavetta testui Bremek. & 0 & 1 & 0 & 0 & 0 & 0 & 0 \\
\hline & Pavetta urophylla ssp. Bosii S. D. Manning & 1 & 0 & 0 & 0 & 0 & 0 & 0 \\
\hline & Pavetta viridiloba var. meurillonii S. D. Manning & 1 & 0 & 0 & 0 & 0 & 0 & 0 \\
\hline & Pavetta viridiloba var. viridiloba & 1 & 0 & 0 & 0 & 0 & 0 & 0 \\
\hline \multirow[t]{2}{*}{ Pentaloncha } & Pentaloncha humilis Hook. f. & 0 & 1 & 0 & 1 & 0 & 0 & 0 \\
\hline & Pentaloncha rubruflora Good & 0 & 0 & 0 & 0 & 1 & 0 & 0 \\
\hline \multirow[t]{2}{*}{ Pentas } & Pentas ledermannii $\mathrm{K}$. Krause & 1 & 0 & 0 & 0 & 0 & 1 & 0 \\
\hline & Pentas nervosa Hepper & 1 & 0 & 0 & 0 & 0 & 1 & 0 \\
\hline \multirow[t]{2}{*}{ Peripeplus } & Peripeplus bracteosus (Hiern) E. M. A. Petit & 0 & 1 & 0 & 0 & 0 & 0 & 0 \\
\hline & Peripeplus klaineanus Pierre & 0 & 1 & 0 & 0 & 0 & 0 & 0 \\
\hline Petitiocodon & Petitiocodon parviflorum (Keay) Robbr. & 1 & 0 & 0 & 0 & 0 & 1 & 0 \\
\hline \multirow{3}{*}{ Poecilocalyx } & Poecilocalyx crystallinus N. Hallé & 0 & 1 & 0 & 0 & 0 & 0 & 0 \\
\hline & Poecilocalyx schumannii Bremek. & 1 & 1 & 0 & 0 & 0 & 0 & 1 \\
\hline & Poecilocalyx setiflorus (R. D. Good) Bremek. & 1 & 1 & 0 & 0 & 1 & 0 & 0 \\
\hline Pouchetia & Pouchetia confertiflora Mildbr. & 0 & 0 & 0 & 0 & 0 & 0 & 0 \\
\hline \multirow[t]{10}{*}{ Pseudosabicea } & Pseudosabicea aurifodinae var. aurifodinae & 0 & 1 & 0 & 0 & 0 & 0 & 0 \\
\hline & Pseudosabicea aurifodinae var. crystallina N. Hallé & 0 & 1 & 0 & 0 & 0 & 0 & 0 \\
\hline & Pseudosabicea batesii (Wernham) N. Hallé & 1 & 1 & 0 & 1 & 0 & 0 & 0 \\
\hline & Pseudosabicea medusula (K. Schum. ex Wernham) N. Hallé & 1 & 1 & 0 & 0 & 0 & 0 & 0 \\
\hline & Pseudosabicea nobilis (R. D. Good) N. Hallé & 0 & 1 & 0 & 0 & 1 & 0 & 0 \\
\hline & Peudosabicea pedicellata (Wernham) N. Hallé & 1 & 1 & 0 & 0 & 0 & 0 & 0 \\
\hline & Pseudosabicea proselyta N. Hallé & 1 & 1 & 0 & 0 & 0 & 0 & 0 \\
\hline & Pseudosabicea sanguinosa N. Hallé & 0 & 1 & 0 & 0 & 0 & 0 & 0 \\
\hline & Pseudosabicea segregata (Hiern) N. Hallé & 1 & 1 & 0 & 0 & 0 & 0 & 0 \\
\hline & Pseudosabicea sthenula N. Hallé & 0 & 1 & 0 & 0 & 0 & 0 & 0 \\
\hline Psychotria & Psychotria aemulans K. Schum. & 1 & 0 & 0 & 0 & 0 & 0 & 0 \\
\hline & Psychotria alatipes Wernham & 1 & 1 & 0 & 0 & 0 & 1 & 0 \\
\hline & Psychotria alluviorum K. Krause & 1 & 0 & 0 & 0 & 0 & 0 & 0 \\
\hline & Psychotria articulata (Hiern) E. M. A. Petit & 1 & 0 & 0 & 0 & 0 & 1 & 0 \\
\hline & Psychotria bakossiensis Cheek \& Sonké & 1 & 0 & 0 & 0 & 0 & 0 & 0 \\
\hline & Psychotria bangweana K. Schum. & 1 & 0 & 0 & 0 & 0 & 0 & 0 \\
\hline & Psychotria barensis $\mathrm{K}$. Krause & 1 & 0 & 0 & 0 & 0 & 0 & 0 \\
\hline & Psychotria batangana K. Schum. & 1 & 0 & 0 & 0 & 0 & 0 & 0 \\
\hline & Psyhotria bifaria Hiern & 1 & 1 & 0 & 0 & 0 & 0 & 1 \\
\hline & Psychotria bimbiensis Bridson \& Cheek & 1 & 0 & 0 & 1 & 0 & 0 & 0 \\
\hline & Psychotria brandneriana (L.Linden) Robbr. & 0 & 1 & 0 & 0 & 0 & 0 & 0 \\
\hline & Psychotria camerunensis E. M. A. Petit & 1 & 0 & 0 & 0 & 0 & 0 & 0 \\
\hline & Psychotria camptopus Verdc. & 1 & 0 & 0 & 0 & 0 & 0 & 1 \\
\hline & Psychotria ceratalabastron K. Schum. & 1 & 0 & 0 & 0 & 0 & 0 & 0 \\
\hline & Psychotria chrysoclada K. Schum. & 1 & 0 & 0 & 0 & 0 & 0 & 0 \\
\hline & Psychotria crassicalyx K. Krause & 0 & 0 & 0 & 0 & 0 & 0 & 1 \\
\hline & Psychotria densinerva (K. Krause) Verdc. & 1 & 0 & 0 & 0 & 0 & 0 & 0 \\
\hline
\end{tabular}


Hermann Taedoumg et al., Sch Acad J Biosci, Mar, 2021; 9(3): 68-83

\begin{tabular}{|c|c|c|c|c|c|c|c|c|}
\hline Genus & Species & छే & है & $\tilde{\theta}$ & 秀 & है & $\stackrel{000}{Z}$ & نِ \\
\hline & Psychotria dimorphophylla K. Schum. & 1 & 0 & 0 & 0 & 0 & 0 & 0 \\
\hline & Psychotria dodoensis K. Krause & 1 & 0 & 0 & 0 & 0 & 0 & 0 \\
\hline & Psychotria dusenii K. Schum. & 1 & 0 & 0 & 0 & 0 & 0 & 0 \\
\hline & Psychotria ebensis K. Schum. & 1 & 1 & 0 & 0 & 0 & 0 & 0 \\
\hline & Psychotria erythropus K. Schum. & 1 & 0 & 0 & 0 & 0 & 0 & 0 \\
\hline & Psychotria fleuryana E. M. A. Petit & 1 & 1 & 0 & 0 & 0 & 0 & 0 \\
\hline & Psychotria foliosa Hiern & 1 & 1 & 0 & 0 & 0 & 0 & 0 \\
\hline & Psychotria gaboonensis Ruhsam. & 0 & 1 & 0 & 0 & 0 & 0 & 0 \\
\hline & Psychotria geophylax Cheek \& Sonké & 1 & 0 & 0 & 0 & 0 & 0 & 0 \\
\hline & Psychotria globiceps K. Schum. & 1 & 0 & 0 & 0 & 0 & 0 & 0 \\
\hline & Psychotria humilis var. humilis & 1 & 1 & 0 & 0 & 0 & 1 & 0 \\
\hline & Psychotria ilendensis K. Krause & 1 & 0 & 0 & 0 & 0 & 0 & 0 \\
\hline & Psychotria infundibularis Hiern & 0 & 1 & 0 & 0 & 0 & 0 & 0 \\
\hline & Psychotria ingentifolia E. M. A. Petit & 1 & 0 & 0 & 0 & 0 & 0 & 0 \\
\hline & Psychotria klainei Schnell & 0 & 1 & 0 & 0 & 0 & 0 & 0 \\
\hline & Psychotria lanceifolia K. Schum. & 1 & 0 & 0 & 0 & 0 & 0 & 0 \\
\hline & Psychotria letouzeyi E. M. A. Petit & 1 & 1 & 0 & 0 & 0 & 0 & 0 \\
\hline & Psychotria leucocentron K. Schum. & 1 & 0 & 0 & 0 & 0 & 0 & 0 \\
\hline & Psychotria martinetugei Cheek & 1 & 0 & 0 & 1 & 0 & 1 & 0 \\
\hline & Psychotria microthyrsa E. M. A. Petit & 1 & 0 & 0 & 0 & 0 & 0 & 0 \\
\hline & Psychotria minima Good & 0 & 0 & 0 & 0 & 1 & 0 & 0 \\
\hline & Psychotria minimicalyx K. Schum. & 1 & 0 & 0 & 0 & 0 & 0 & 0 \\
\hline & Psychotria moliwensis Bridson \& Cheek & 1 & 0 & 0 & 0 & 0 & 0 & 1 \\
\hline & Psychotria mollipes $\mathrm{K}$. Krause & 0 & 0 & 0 & 0 & 0 & 0 & 0 \\
\hline & Psychotria moseskemei Cheek & 1 & 0 & 0 & 0 & 0 & 1 & 1 \\
\hline & Psychotria muschleriana $\mathrm{K}$. Krause & 1 & 0 & 0 & 0 & 0 & 0 & 0 \\
\hline & Psychotria nebulosa K. Krause & 1 & 0 & 0 & 0 & 0 & 0 & 0 \\
\hline & Psychotria oblanceolata (R. D. Good) Ruhsam. & 0 & 0 & 0 & 0 & 1 & 0 & 0 \\
\hline & Psychotria oligocarpa K. Schum. & 1 & 0 & 0 & 0 & 0 & 0 & 0 \\
\hline & Psychotria owariensis (P.Beauv.) Hiern & 0 & 0 & 0 & 0 & 0 & 0 & 1 \\
\hline & Psychotria perbrevis K. Schum. & 1 & 0 & 0 & 0 & 0 & 0 & 0 \\
\hline & Pschotria piolampra K. Schum. & 1 & 0 & 0 & 0 & 0 & 1 & 0 \\
\hline & Psychotria pleuroneura K. Schum. & 1 & 0 & 0 & 0 & 0 & 0 & 0 \\
\hline & Psychotria podocarpa E. M. A. Petit & 1 & 0 & 0 & 0 & 0 & 1 & 0 \\
\hline & Psychotria principensis G. Taylor & 0 & 1 & 0 & 0 & 0 & 0 & 1 \\
\hline & Psychotria rambouensis De Wild. & & 0 & 0 & 0 & 0 & 0 & 0 \\
\hline & Psychotria recurva Hiern in D. Oliver \& auct. suc. (eds.) & 0 & 0 & 0 & 0 & 0 & 0 & 1 \\
\hline & Psychotria refractiflora $\mathrm{K}$. Schum. & 0 & 1 & 0 & 0 & 0 & 0 & 0 \\
\hline & Psychotria rhizomatosa var. minor E. M. A. Petit & 1 & 1 & 0 & 0 & 0 & 0 & 0 \\
\hline & Psychotria rubropilosa De Wild. & 0 & 1 & 0 & 0 & 0 & 0 & 0 \\
\hline & Psychotria sycophylla (K. Schum.) E. M. A. Petit & 1 & 0 & 0 & 0 & 0 & 0 & 0 \\
\hline & Psychotria talbotii Wernham & 1 & 0 & 0 & 0 & 0 & 1 & 0 \\
\hline & Psychotria trichanthera K. Schum. & 1 & 0 & 0 & 0 & 0 & 0 & 0 \\
\hline Psydrax & Psydrax bridsoniana Cheek \& Sonké & 1 & 0 & 0 & 0 & 0 & 0 & 0 \\
\hline & Psydrax dunlapii (Hutch. \& Daziel) Bridson & 1 & 0 & 0 & 0 & 0 & 1 & 1 \\
\hline Pyrostria & Pyrostria bispathacea (Mildbr.) Bridson & 1 & 0 & 0 & 0 & 0 & 0 & 0 \\
\hline Rothmannia & Rothmannia ebamutensis Sonké & 1 & 0 & 0 & 0 & 0 & 0 & 0 \\
\hline & Rothmannia jollyana N. Hallé & 0 & 1 & 0 & 0 & 0 & 0 & 0 \\
\hline Rutidea & Rutidea ferruginea Hiern & 0 & 1 & 0 & 0 & 0 & 0 & 0 \\
\hline & Rutidea gabonensis Bridson & 0 & 1 & 0 & 0 & 0 & 0 & 0 \\
\hline & Rutidea glabra Hiern & 1 & 1 & 1 & 0 & 0 & 1 & 0 \\
\hline & Rutidea gracilis var. makokounsis Bridson & 0 & 1 & 0 & 0 & 0 & 0 & 0 \\
\hline & Rutidea tenuiccaulis $\mathrm{K}$. Krause & 1 & 0 & 0 & 0 & 0 & 0 & 0 \\
\hline Rytigynia & Rytigynia ferruginea Robyns & 1 & 0 & 0 & 0 & 0 & 0 & 0 \\
\hline & Rytigynia goosweileri Robyns & 0 & 1 & 0 & 0 & 0 & 0 & 0 \\
\hline & Rytiginia krauseana Robyns & 1 & 0 & 0 & 0 & 0 & 0 & 0 \\
\hline & Rytigynia lecomtei Robyns & 0 & 1 & 1 & 0 & 0 & 0 & 0 \\
\hline & Rytigynia mayumbensis Robyns & 0 & 1 & 0 & 0 & 0 & 0 & 0 \\
\hline & Rytiginia membranacea (Hiern) Robyns & 1 & 0 & 0 & 0 & 0 & 1 & 0 \\
\hline & Rytigynia subbiflora (Mildbr.) Robyns & 1 & 0 & 0 & 0 & 0 & 0 & 0 \\
\hline
\end{tabular}


Hermann Taedoumg et al., Sch Acad J Biosci, Mar, 2021; 9(3): 68-83

\begin{tabular}{|c|c|c|c|c|c|c|c|c|}
\hline Genus & Species & छ & है & ¿ี & ర్య & है & $\stackrel{000}{Z}$ & ن \\
\hline \multirow[t]{23}{*}{ Sabicea } & Sabicea amomii Wernham & 1 & 0 & 0 & 0 & 0 & 0 & 0 \\
\hline & Sabicea bigerrica N. Hallé & 0 & 1 & 0 & 0 & 0 & 0 & 0 \\
\hline & Sabicea brachiata Wernham & 1 & 0 & 0 & 0 & 0 & 0 & 0 \\
\hline & Sabicea cameroonensis Wernham & 1 & 1 & 0 & 0 & 1 & 0 & 0 \\
\hline & Sabicea caminata N. Hallé & 0 & 1 & 0 & 0 & 0 & 0 & 0 \\
\hline & Sabicea capitellata Benth. & 1 & 1 & 1 & 0 & 0 & 1 & 1 \\
\hline & Sabicea composita Wernham & 1 & 0 & 0 & 0 & 0 & 0 & 0 \\
\hline & Sabicea cruciata Wernham & 1 & 0 & 0 & 0 & 0 & 0 & 0 \\
\hline & Sabicea efulenensis (Hutch.) Hepper & 1 & 1 & 0 & 0 & 0 & 1 & 0 \\
\hline & Sabicea fulva Wernham & 1 & 1 & 0 & 0 & 0 & 0 & 0 \\
\hline & Sabicea gabonica (Hiern) Hepper & 1 & 1 & 0 & 0 & 0 & 1 & 0 \\
\hline & Sabicea gracilis Wernham & 1 & 0 & 0 & 0 & 0 & 0 & 0 \\
\hline & Sabicea laxa Wernham & 1 & 0 & 0 & 0 & 0 & 0 & 0 \\
\hline & Sabicea leucocarpa (K. Krause) Mildbr. & 1 & 0 & 0 & 0 & 0 & 0 & 0 \\
\hline & Sabicea najatrix N. Hallé & 1 & 1 & 0 & 0 & 0 & 0 & 0 \\
\hline & Sabicea rufa Wernham & 1 & 1 & 0 & 0 & 0 & 0 & 0 \\
\hline & Sabicea schaeferi Wernham & 1 & 0 & 0 & 0 & 0 & 0 & 1 \\
\hline & Sabicea spesiosissima K. Schum. & 1 & 0 & 0 & 0 & 0 & 0 & 0 \\
\hline & Sabicea stipularioides Wernham & 1 & 0 & 0 & 0 & 0 & 0 & 0 \\
\hline & Sabicea trigemina K. Schum. & 1 & 1 & 0 & 0 & 0 & 0 & 0 \\
\hline & Sabicea urbaniana Wernham & 1 & 0 & 0 & 0 & 0 & 0 & 1 \\
\hline & Sabicea urceolata Hepper & 0 & 0 & 0 & 0 & 0 & 1 & 1 \\
\hline & Sabicea xanthotricha Wernham & 1 & 0 & 0 & 0 & 0 & 1 & 0 \\
\hline \multirow{2}{*}{$\begin{array}{l}\text { Schumanniophyt } \\
\text { on }\end{array}$} & Schumanniophyton klaineanum Perre ex A.Chev. & 0 & 1 & 0 & 0 & 0 & 0 & 0 \\
\hline & Schumanniophyton trimerum Good & 1 & 1 & 0 & 0 & 0 & 0 & 0 \\
\hline \multirow[t]{5}{*}{ Sericanthe } & Sericanthe jacfelicis (N. Hallé) Robbr. & 1 & 0 & 1 & 0 & 0 & 0 & 0 \\
\hline & Sericanthe lowryana (inédit) & 1 & 0 & 0 & 0 & 0 & 0 & 0 \\
\hline & Sericanthe petitii (N. Hallé) Robbr. & 0 & 1 & 0 & 0 & 0 & 0 & 0 \\
\hline & Sericanthe raynaliorum (N. Hallé) Robbr. & 1 & 0 & 0 & 0 & 0 & 0 & 0 \\
\hline & Sericanthe testui var. pseudosalacina (N. Hallé) Robbr. & 0 & 1 & 0 & 0 & 0 & 0 & 0 \\
\hline \multirow[t]{7}{*}{ Sherbournia } & Sherbournia ailarama. $\mathrm{N}$ Hallé & 1 & 1 & 0 & 1 & 0 & 0 & 1 \\
\hline & Sherbournia buccularia N. Hallé & 1 & 1 & 0 & 1 & 0 & 0 & 0 \\
\hline & Sherbournia hapalophylla ssp. hapalophylla & 1 & 1 & 1 & 1 & 0 & 1 & 0 \\
\hline & Sherbournia kiliotricha N. Hallé & 0 & 1 & 0 & 0 & 0 & 0 & 0 \\
\hline & Sherbournia millenii & 1 & 0 & 0 & 0 & 0 & 1 & 0 \\
\hline & Sherbournia myosura N. Hallé & 0 & 1 & 1 & 0 & 0 & 0 & 0 \\
\hline & Sherbournia streptocaulon (K. Schum.) Hepper & 1 & 1 & 0 & 1 & 0 & 0 & 0 \\
\hline \multirow[t]{4}{*}{ Spermacoce } & Spermacoce garuensis (K. Krause) Govaerts & 1 & 0 & 0 & 0 & 0 & 0 & 0 \\
\hline & Spermacoce ledermannii (K. Krause) Govaerts & 1 & 0 & 0 & 0 & 0 & 0 & 0 \\
\hline & Spermacoce malacophylla (K. Schum.) Govaerts & 1 & 0 & 0 & 0 & 0 & 0 & 0 \\
\hline & Spermacoce spermacocina (K. Schum.) Bridson \& Puff & 1 & 0 & 0 & 0 & 0 & 1 & 0 \\
\hline \multirow[t]{3}{*}{ Stelechantha } & Stelechantha arcuata S. E. Dawson & 1 & 0 & 0 & 0 & 0 & 0 & 0 \\
\hline & Stelechantha cauliflora (R. D. Good) Bremek. & 1 & 1 & 0 & 0 & 1 & 0 & 0 \\
\hline & Stelechantha makakana N. Hallé & 1 & 0 & 0 & 0 & 0 & 0 & 0 \\
\hline \multirow[t]{5}{*}{ Tarenna } & Tarenna calliblepharis N. Hallé & 0 & 1 & 0 & 0 & 0 & 0 & 0 \\
\hline & Tarenna eketensis var. situtela $\mathrm{N}$. Hallé & 1 & 1 & 0 & 0 & 0 & 0 & 0 \\
\hline & Tarenna grandiflora (Benth.) Hiern & 1 & 0 & 1 & 0 & 0 & 1 & 1 \\
\hline & Tarenna jolinonii N. Hallé & 0 & 1 & 0 & 0 & 0 & 0 & 0 \\
\hline & Tarenna scandens Good & 0 & 1 & 0 & 0 & 0 & 0 & 0 \\
\hline Temnopterix & Temnopterix sericea Hook. f. & 1 & 1 & 0 & 1 & 0 & 0 & 0 \\
\hline \multirow{9}{*}{ Tricalysia } & Tricalysia achoundongiana Robbr., Sonké \& Kenfack & 1 & 0 & 0 & 1 & 0 & 0 & 0 \\
\hline & Tricalysia amplexicaulis Robbr. & 1 & 0 & 0 & 0 & 0 & 0 & 0 \\
\hline & Tricalysia atherura N. Hallé & 1 & 1 & 0 & 0 & 0 & 0 & 0 \\
\hline & Tricalysia concolor $\mathrm{N}$. Hallé & 0 & 1 & 0 & 0 & 0 & 0 & 0 \\
\hline & Tricalysia fangana (N. Hallé) Robbr. & 1 & 1 & 0 & 0 & 0 & 0 & 0 \\
\hline & Tricalysia ferorum Robbr. & 1 & 0 & 0 & 0 & 0 & 0 & 0 \\
\hline & Tricalysia idiura N. Hallé & 0 & 1 & 0 & 0 & 0 & 0 & 0 \\
\hline & Tricalysia lasiodelphys ssp. anomalura (N. Hallé) Robbr. & 1 & 1 & 0 & 0 & 0 & 0 & 0 \\
\hline & Tricalysia lasiodelphys ssp. lasiodelphys & 1 & 0 & 0 & 0 & 0 & 0 & 0 \\
\hline
\end{tabular}




\begin{tabular}{|c|c|c|c|c|c|c|c|c|}
\hline Genus & Species & छే & है & $\tilde{\theta}$ & 秀 & है & $\stackrel{000}{Z}$ & نِ \\
\hline & Tricalysia ledermannii $\mathrm{K}$. Krause & 1 & 0 & 0 & 0 & 0 & 0 & 0 \\
\hline & Tricalysia lejolyana Sonké \& Cheek & 1 & 0 & 0 & 0 & 0 & 0 & 0 \\
\hline & Tricalysia lineariloba Hutch. & 1 & 0 & 0 & 0 & 0 & 0 & 0 \\
\hline & Tricalysia longipaniculata Good & 0 & 1 & 0 & 0 & 0 & 0 & 0 \\
\hline & Tricalysia obstetrix $\mathrm{N}$. Hallé & 1 & 1 & 1 & 0 & 0 & 0 & 0 \\
\hline & Tricalysia pangolina N. Hallé & 1 & 1 & 1 & 0 & 0 & 0 & 0 \\
\hline & Tricalysia patentipilis $\mathrm{K}$. Krause & 1 & 0 & 0 & 0 & 0 & 0 & 0 \\
\hline & Tricalysia pedunculosa var. pedunculosa & 1 & 1 & 0 & 0 & 0 & 0 & 0 \\
\hline & Tricalysia pedunculosa var. pilosula (N. Hallé) Robbr. & 0 & 0 & 0 & 0 & 0 & 0 & 0 \\
\hline & Tricalysia pedunculosa var. walkeriana (N. Hallé) Robbr. & 0 & 1 & 0 & 0 & 0 & 0 & 0 \\
\hline & Tricalysia potamogala N. Hallé & 0 & 1 & 0 & 0 & 0 & 0 & 0 \\
\hline & Tricalysia soyauxii K. Schum. & 1 & 1 & 0 & 0 & 0 & 0 & 0 \\
\hline & Tricalysia subsessilis K. Schum. & 1 & 0 & 0 & 0 & 0 & 0 & 0 \\
\hline & Tricalysia sylvae Robbr. & 1 & 1 & 0 & 0 & 0 & 0 & 0 \\
\hline & Tricalysia talbotii (Wernham) Keay & 1 & 0 & 0 & 0 & 0 & 1 & 0 \\
\hline & Tricalysia vadensis Robbr. & 1 & 0 & 0 & 0 & 0 & 0 & 0 \\
\hline \multirow[t]{7}{*}{ Trichostachys } & Trichostachys interrupta K. Schum. & 1 & 0 & 0 & 0 & 0 & 1 & 0 \\
\hline & Trichostachys le-testui Pellegr. & 0 & 1 & 0 & 0 & 0 & 0 & 0 \\
\hline & Trichostachys lehmbachii K. Schum. & 1 & 0 & 0 & 0 & 0 & 0 & 0 \\
\hline & Trichostachys longifolia Hiern & 0 & 1 & 0 & 0 & 0 & 0 & 0 \\
\hline & Trichostachys petiolata Hiern & 1 & 0 & 0 & 0 & 0 & 0 & 0 \\
\hline & Trichostachys soyauxii K. Schum. & 0 & 1 & 0 & 0 & 0 & 0 & 0 \\
\hline & Trichostachys stenotachys K. Schum. & 0 & 1 & 0 & 0 & 0 & 0 & 0 \\
\hline \multirow[t]{7}{*}{ Vangueriella } & Vangueriella chlorantha (K. Schum.) Verdc. & 1 & 1 & 0 & 1 & 0 & 1 & 0 \\
\hline & Vangueriella georgesii Verdc. & 0 & 1 & 0 & 0 & 0 & 0 & 0 \\
\hline & Vangueriella laxiflora (K. Schum.) Verdc. & 1 & 1 & 0 & 0 & 0 & 1 & 0 \\
\hline & Vangueriella letestui Verdc. & 0 & 1 & 0 & 0 & 0 & 0 & 0 \\
\hline & Vangueriella rufa (Robyns) Verdc. & 0 & 1 & 0 & 0 & 0 & 0 & 0 \\
\hline & Vangueriella soyauxii (K. Schum.) Verdc. & 0 & 1 & 0 & 0 & 0 & 0 & 0 \\
\hline & Vangueriella zenkeri Verdc., & 1 & 0 & 0 & 0 & 0 & 0 & 0 \\
\hline \multirow[t]{5}{*}{ Virectaria } & Virectaria angustifolia var. angustifolia & 1 & 1 & 0 & 0 & 0 & 1 & 0 \\
\hline & Virectaria angustifolia var. schlechteri Verdc. & 1 & 0 & 0 & 0 & 0 & 0 & 0 \\
\hline & Virectaria belingana N. Hallé & 1 & 1 & 0 & 0 & 0 & 0 & 0 \\
\hline & Virectaria herbacoursi var. herbacoursii & 1 & 0 & 0 & 0 & 0 & 0 & 0 \\
\hline & Virectaria herbacoursi var. petrophila N. Hallé & 1 & 0 & 0 & 0 & 0 & 0 & 0 \\
\hline
\end{tabular}

\section{REFERENCES}

1. Taedoumg H. Taxonomie du genre Craterispermum Benth. (Genianales - Rubiaceae) en Afrique continentale - Méthodologie de révision taxonomique chez les Angiospermes. Abc Taxa 20; 2020.

2. Roe D, Thomas D, Smith J, Walpole M, Elliott J. Biodiversité et pauvreté: dix questions fréquemment posées, dix implications politiques. Gatekeeper series, 2011.

3. Vande weghe JP. Forêts d'Afrique centrale: la nature et l'Homme. Editions Lannoo SA, Tielt, Belgique; 2004.

4. Sonké B, Nguembou KC, Danho N. Les Rubiaceae endémiques du Cameroun. in: Taxonomy and ecology of African plants, their conservation ands uses. Beedje H \& Ghazanfar S (eds). Royal Botanic Gardens, Kew, 2006; 97-109.

5. Sosef MSM. New species of Begonias in Africa and their relevance to study of glacial rain forest refuges. Wageningen Agricultural University Papers. 1992; 91 (4): 117-151.
6. Sosef MSM. Refuge Begonias: Taxonomy, phylogeny and historical biogegraphy of Begonias sect. Loasibegonias and sect. Scutobegonias in relation to glacial rain forest refuges in Africa. Wageningen Agricultural University Papers. 1994; 94 (1): 1-306.

7. Sosef MSM. Begonias and African rain forest refuges: General aspects and recent progress. In: The Biodiversity of African plant. Van Der Maesen LJG, Van Der Burgt XM, Van Mendenbach De Rooy JM (eds).Wagenigen, 1996; 14: 602-611.

8. Govavaerts R, Ruhsam M, Andersson L, Robbrecht E, Bridson DM, Davis AP, Schanzer I, Sonke B. The World Checklist of Rubiaceae. Royal Botanic Gardens, Kew. Available from http://www.kew.org/wcsp (consulted in 2018)

9. Lejoly J. Activités prioritaires pour le « volet biodiversité $»$. Termes de références. Rapport ECOFAC, 2000.

10. Robbrecht E. Tropical woody Rubiaceae. Characteristic features and progressions. Contributions to a new subfamilial classification. Opera Botanica Belgica, 1988. 
Hermann Taedoumg et al., Sch Acad J Biosci, Mar, 2021; 9(3): 68-83

11. Droissart V, Sonké B, Hardy O, Simo M, Taedoumg H, Nguembou KC, Stévart T. Do plant families with contrasting functional traits show similar patterns of endemism? A case study with Central African Orchidaceae and Rubiaceae. Biodiversity Conservation. 2011; 20 (7): 1507-1531.

12. White F. The Guineo-Congolian region and its relationships to other phytochoria. Bulletin du Jardin Botanique National de Belgique. 1979; 49: 11-55.

13. Holmgren P K, Holmgren NH, Barnett LC. Index Herbariorium. Part 1. The Herbaria of the world. The New York Botanic Garden Press, New York, 1990.

14. Cable S, Cheek M. The plants of mount Cameroon. A conservation checklist. Royal Botanic Gardens Kew; 1998.

15. Cheek M, Onana JM, Pollard J. The plants of mount $\mathrm{Oku}$ and the Ijim Ridge, Cameroon. A conservation check-list. Royal Botanic Gardens Kew; 2000.

16. Cheek M, Pollard J, Onana JM, Barbyshire I, Wild C. The plants of Kupe, Mwanenguba and the Bakossi Mountains, Cameroon. A conservation checklist. Royal Botanic Gardens Kew; 2004.

17. Harley Y, Pollard BJ, Dardyshire I, Onana JM, Cheek M. The plants of Bali Nguemba forest Reserve, Cameroon. A conservation checkist. Royal Botanic Gardens Kew; 2004.

18. Anonyme. Cameroon official standard names approved by the united board on geographic nac: Gazetter 60. Office of geographic, department of interior, Washington D.C. 1962.

19. Nguembou KC, Sonké B, Zapfack L, Lejoly J. Les espèces Camerounaises du genre Bertiera (Rubiaceae). Systematics and Geography of Plants. 2003; 73: 237-280.

20. Beina D. Etude de la flore des Rubiaceae de la région de Bangui (République Centrafricaine). Mémoire de DEA, Université de Yaoundé I. 2004; 1- 111.

21. Letouzey R. Notice de la carte phytogéographique du Cameroun au 1/500.000. Domaine de la forêt dense humide semi-caducifoliée, Domaine de la forêt dense toujours verte. Institut de la Carte Internationale de la Végétation, Toulouse. 1985; 62-94 \& 95-142.

22. Linder HP. Plant diversity and endemism in subsaharian tropical Africa. Journal of Biogeography. 2001; 28: 169-182.
23. Stévart T. Etude taxonomique, écologique et phytogéographique des Orchidaceae en Afrique centrale atlantique. Thèse de Doctorat en sciences, Université Libre de Bruxelles. 2003; 1-225.

24. Sonké B, Bridson DM. Une nouvelle espèce d'Aulacocalyx (Rubiaceae, Aulacocalyceae) du Sud-Ouest du Cameroun. Systematics and Geography of Plants. 2001. 71(1): 17-23.

25. Sonké B., Cheek M., Nambu D. M. \& Robbrecht E. A new species of Tricalysia A. Rich. (Rubiaceae) from western Cameroon. Kew Bulletin. 2002; 57(3): 681-686.

26. Sonké B, Stoffelen P. Une nouvelle espèce de Coffea L. (Rubiaceae, Coffeeae) du Cameroun, avec quelques notes sur ses affinités avec les espèces voisines. Adansonia. 2004; 3, 26(2): 153-160.

27. Sonké B, Dawson S, Beina D. A new species of Aulacocalyx (Rubiaceae - Gardenieae) from southern Cameroon. Kew Bulletin. 2005; 60(2): 301-304.

28. Nguembou KC, Esono P, Onana JM, Sonké B. Un Bertiera (Rubiaceae) nouveau et hétérophylle du Cameroun et du Gabon. Systematics and Geography of Plants. 2006; 76(2): 211-216.

29. Sonké B., Nguembou KC, Cheek M, Davis AP. A new species of Chassalia (Rubiaceae, Rubioideae) from southern Cameroon: C. bipindensis. Kew Bulletin. 2006; 61(4): 585-589.

30. Sonké B, Nguembou KC, Davis AP. A new dwarf Coffea (Rubiaceae) from southern Cameroon. Botanical Journal of Linnean Society. 2006; 151(3): 425-430.

31. Robbrecht E. Geography of African Rubiaceae with reference to glacial rain forest refuges. In: The Biodiversity of African plant. Van Der Maesen LJG, Van Der Burgt XM, Van Mendenbach De Rooy J M (eds).Wagenigen, 1996; 14: 564-581.

32. Droissart V, Sonké B, Stévart T. Les Orchidaceae endémiques d'Afrique centrale Atlantique présentes au Cameroun. Systematics and Geography of Plants. 2006; 76: 3-84.

33. Linder HP. Gene flow, speciation and species diversity patterns in a species area. In: The Cape Flora. Species and speciation. Vrbra ES (ed). Pretoria Transval Museum Monographs. 1985; 53-57. 